\title{
Sources and hydrothermal alteration of organic matter in Quaternary sediments: a synthesis of studies from the Central Gulf of California
}

\author{
Bernd R. T. Simoneit \\ College of Oceanography, Oregon State University, Corvallis, Oregon 97331, USA \\ and Colin P. Summerhayes \\ The British Petroleum Company, BP Research Centre, Chertsey Road, \\ Sunbury-on-Thames, Middlesex, England \\ and Philip A. Meyers \\ Oceanography Program, Department of Atmospheric and Oceanic Science, The \\ University of Michigan, Ann Arbor, Michigan 48109, USA \\ Received 15 June 1985; revised 9 April 1986

\begin{abstract}
Deep sea drilling in the Central Gulf of California, a young and active spreading centre, shows that the high heat flow typical of these regions causes extensive alteration of sediment organic matter, especially near sills and above magma chambers where hydrothermal activity is concentrated. Even on the nearby passive margin, where there are no sills, heat flow is moderately high and hydrocarbon generation has begun in immature sequences. Migrating light hydrocarbons are detected especially where hydrothermal activity is concentrated. Thermogenic methane is more widespread, though not in the passive margin bordering the spreading centre. Despite the incidence of hydrocarbon generation and migration, the amounts of hydrocarbons involved are relatively small and apparently do not lead to commercially significant accumulations of petroleum.

The organic matter in these sediments is mostly marine because the Gulf of California generally has low runoff from land and highly productive surface waters. Turbidites rich in terrigenous organic material are locally abundant in the mainly pelagic section in the Guaymas Basin. The highest concentrations of organic matter are found in laminated diatomites deposited on the Guaymas passive margin within the oxygen minimum zone.
\end{abstract}

Keywords: Guaymas Basin; Hydrothermal activity; Organic matter maturation; Hydrocarbon generation; Synthesis DSDP data; Lipids; TOC; Vitrinite reflectance; Pyrolysis

\section{Introduction}

The Gulf of California is a fascinating natural laboratory for the study of organic and inorganic processes within a young and growing ocean basin. These processes, and their sedimentary consequences, may be the direct analogues of those similar, ancient, spreading centres now buried deep beneath the world's passive continental margins. The study of these sediments, in particular of their organic geochemistry, can be the basis for modelling the petroleum geochemistry of such ancient analogues.

In this paper we present a synthesis of the results of organic geochemical studies carried out on sediments drilled in the Gulf of California on Leg 64 of the Deep Sea Drilling Project (DSDP). These studies were carried out as part of the main objectives of Leg 64, namely (1), to establish the history of spreading, to explore for hydrothermal alteration products in areas of high heat flow, and to investigate the hydrocarbon content and maturity of organic matter in these areas by drilling in the spreading centres deep in the Guaymas Basin (Figures 1 and 2), to establish the history of climate-controlled biogenic sedimentation in the oxygen minimum zone beneath the highly productive upwelling surface waters of the Gulf by coring the laminated diatomites (which may be modern analogues of the Miocene Monterey Formation) on the passive margin of the Basin (Figure l) (Curray, Moore et al., 1982).

Our synthesis was designed to answer fundamental

0264-8172/86/040282-16 \$03.00

1986 Butterworth \& Co. (Publishers) Ltd

questions about the sources, deposition, preservation, and alteration of organic matter in sediments from these two main environments - the spreading centre and the nearby passive margin. Because organic matter preserves a record of sedimentary transport processes, of surface water productivity, of the degree of oxygenation of bottom water, and of the magnitude of subsurface diagenetic processes and is more sensitive than other geological thermometers to thermal effects, the answer to these questions may help geologists determine the extent and degree of influences not only of paleonvironmental factors, but also of geothermal processes on sediments in this and other spreading centres.

The contrast in thermal regimes between the Gulf floor and the passive margin in the Guaymas Basin is quite striking and provides a unique opportunity to observe the effects of thermal alteration on young sediments. Some of the sediments in the Guaymas Basin have reached temperatures of $200^{\circ}$ to $300^{\circ} \mathrm{C}$ (Gieskes et al, 1982a), whereas sediments of the same age on the nearby margin have normal geothermal gradients (Curray, Moore et al., 1982).

\section{Discussion}

Our discussion is divided into two sections. The first presents the results of studies carried out on sediments from drill sites in the Guaymas Basin (Figure 1). DSDP Sites 477,478 , and 481 are at water depths of $c a .2000$ $\mathrm{m}$ and are located in or close to a seafloor spreading 

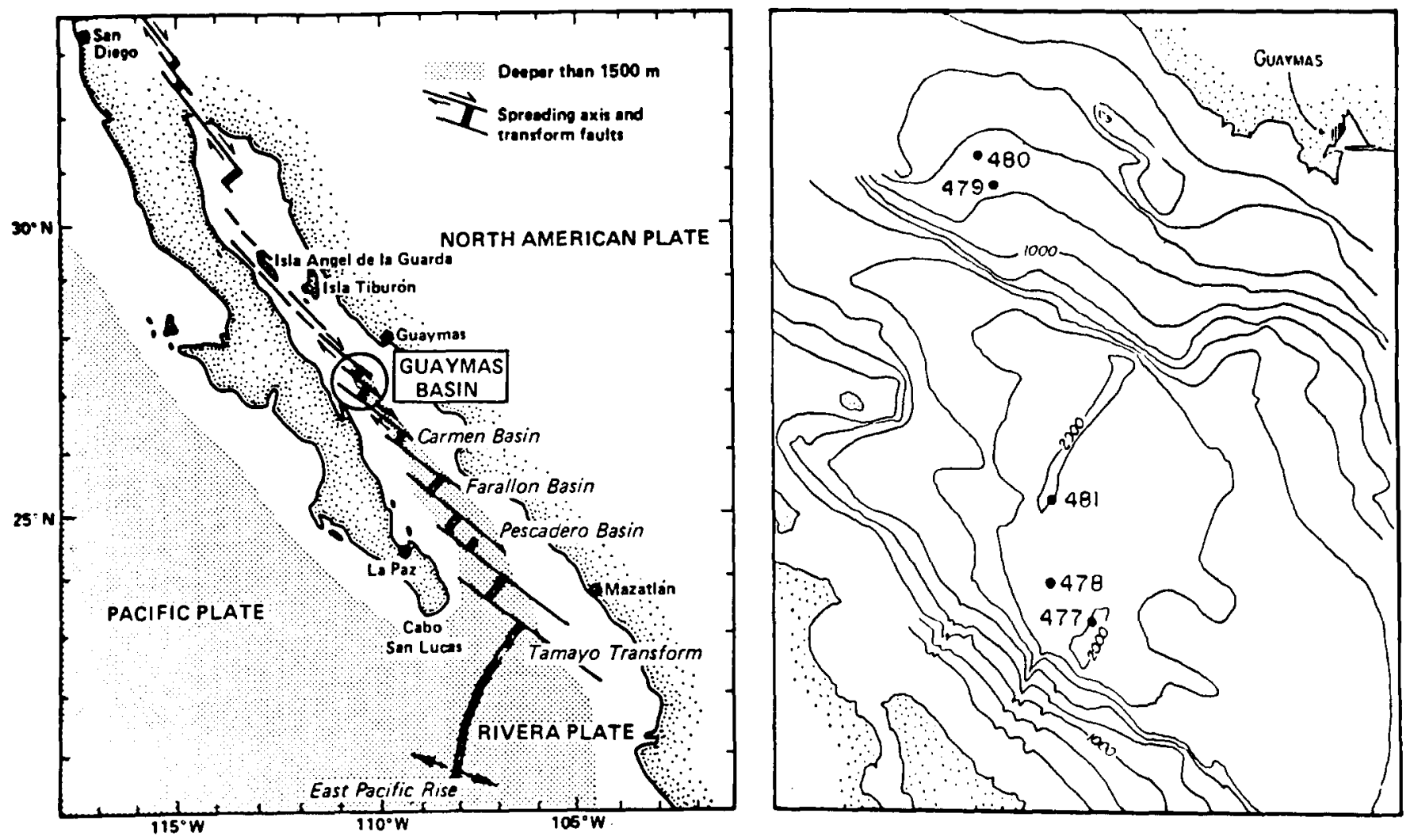

Figure 1 Left-general geographic and tectonic setting of the Guaymas Basin. Right- locations of DSDP Leg 64 sites discussed in this report. Water depths are given in metres.

centre in a region of relatively high heat flow having igneous intrusions in the marine sediments (Table 1 ). The second section is concerned with a contrasting sedimentary environment - the Guaymas continental slope - where DSDP Sites 479 and 480 are at water depths of $c a .700 \mathrm{~m}$ in an oxygen minimum zone under a region of high marine productivity. In both these sections we integrate the geochemical data of a number of investigators with the geological and biological information pertinent to the respective sediments.

Where we present data from a specific sample, we use the DSDP conventional identification system. This system is unique to scientific ocean drilling and is detailed in each volume of the Initial Reports of the Deep Sea Drilling Project. In brief, each sample of rock or sediment is labelled by drill hole-core number-section of the core-centimeters within the section. As an example, sample $481 \mathrm{~A}-6-5,118-120 \mathrm{~cm}$ is from Hole 481A (the second hole at drill site 481), core 6, section 5, 118-120 cm. During Leg 64, drilled cores were $9 \mathrm{~m}$ in length, and HPC (hydraulic piston cores) were $4.5 \mathrm{~m}$ long. Each core is cut into $1.5 \mathrm{~m}$ sections to facilitate handling and storage.

\section{Guaymas Basin}

The Guaymas Basin is an actively spreading oceanic basin that includes two well-defined rifts separated by a $20 \mathrm{~km}$ long transform fault zone (Curray et al., 1979, 1982). High sedimentation rates keep the basin floor while new ocean crust forms. Site 477 is located in the southern rift, Site 481 in the northern one, and Site 478 is on the flank of a spreading rift in the transform fault zone (Curray et al., 1979, 1982). The sediments are

Table 1 Description of sites sampled during DSDP leg 64 in the Gulf of California

\begin{tabular}{|c|c|c|c|c|c|}
\hline \multirow[b]{2}{*}{ DSDP Sites } & \multicolumn{3}{|c|}{ Guaymas Basin } & \multicolumn{2}{|c|}{$\begin{array}{l}\text { Guaymas } \\
\text { Continental Slope }\end{array}$} \\
\hline & 477 & 478 & 481 & 479 & 480 \\
\hline Water depth (m) & 2020 & 1899 & 1998 & 747 & 655 \\
\hline Sediment type & $\begin{array}{l}\text { diatom oozes } \\
\text { and mud turbidites } \\
\text { with dolerite sill } \\
\text { and hydrothermal } \\
\text { alterations }\end{array}$ & $\begin{array}{c}\text { diatom oozes } \\
\text { and silty } \\
\text { turbidites } \\
\text { with dolerite } \\
\text { sills }\end{array}$ & $\begin{array}{l}\text { diatom muds, } \\
\text { muddy sands } \\
\text { and laminated } \\
\text { muds with } \\
\text { dolerite sills }\end{array}$ & $\begin{array}{l}\text { laminated } \\
\text { diatom } \\
\text { muds and } \\
\text { mudstones }\end{array}$ & $\begin{array}{c}\text { laminated } \\
\text { diatom } \\
\text { ooze }\end{array}$ \\
\hline $\begin{array}{l}\text { Deepest sediment } \\
\text { recovered (m) }\end{array}$ & 267.5 & 342.5 & 384.0 & 440 & 152 \\
\hline $\begin{array}{l}\text { Age of oldest } \\
\text { sediment }\end{array}$ & $\begin{array}{c}\text { late } \\
\text { Quaternary }\end{array}$ & $\begin{array}{c}\text { late } \\
\text { Quaternary }\end{array}$ & $\begin{array}{c}\text { late } \\
\text { Quaternary }\end{array}$ & $\begin{array}{c}\text { late } \\
\text { Quaternary }\end{array}$ & Quaternary \\
\hline $\begin{array}{l}\text { Heat flow units } \\
\left.\text { ( } \mu \text { cal } \mathrm{cm}^{-2} \mathrm{~s}^{-1}\right)\end{array}$ & $14-30$ & $3-4$ & $2-3$ & $2-3$ & $\begin{array}{c}\text { not } \\
\text { measured }\end{array}$ \\
\hline
\end{tabular}


Hydrothermal alteration of organic matter: B. R. T. Simoneit et al.

diatomaceous oozes and clastic turbidites, with occasional dolerite intrusions (Table 1). The oldest sediment recovered from these sites was late Pleistocene in age. Site 477 is in the area with the highest heat flow ( 30 Heat Flow Units, HFU), and Site 481 is in an area with slightly higher heat flow (about 4 HFU) than Site 478 (Curray et al., 1979, 1982).

The major questions that we address here are the sources of the organic matter and the extent to which it has been affected by thermal stress from both the high heat flow and the intrusions of sills and dykes.

Gieskes et al. (1982a) use inorganic geochemical and mineralogical evidence to suggest that there are two different types of hydrothermal activity within the Guaymas Basin (Figure 2). One, associated with the emplacement of dolerite sills into highly porous sediments under a thin sediment cover, is of short duration. The second type of hydrothermal activity is associated with large magmatic intrusions under a thick sediment cover, and is of greater longevity. It is typical of the deeper section at Site 477, where it has led to (1), sediment temperatures of $200^{\circ}-300^{\circ} \mathrm{C} ;(2)$, greenschist metamorphism; (3), substantial changes in pore water chemistry; (4), low $\delta^{18} \mathrm{O}$ values in silicates; and (5), low ${ }^{87} \mathrm{Sr} /{ }^{86} \mathrm{Sr}$ ratios in pore waters.

\section{Sources of organic matter}

The sources of the organic matter in the sediments of the basin have been interpreted to be both terrigenous and marine (Table 2). The terrigenous components of extractable lipids appear to be more dominant at Site 481 , which is closer to the outflow of the Yaqui River, than at the other two sites. Site 477, farthest from the river, has the least terrigenous character (Simoneit and Philp, 1982).

At Site 477 , the $n$-alkanes of samples unaltered by heating exhibit a dominance of the odd carbon number homologues larger than $\mathrm{C}_{27}$, indicative of terrigenous sources, with significant components lower than $\mathrm{C}_{21}$ that are of a marine origin (Galimov et al., 1982, Simoneit and Philp, 1982; Simoneit et al., 1984). However, the stable carbon isotope compositions of the total lipid extracts (which are dominated by polar components) fall within the range typical of marine detritus $\left(\delta^{13} \mathrm{C}\right.$ about $-22 \%$,: Galimov et al., 1982). Molecular markers, such as steroids and triterpenoids, in the shallow sediments have distributions and configurations indicative of recent marine biosynthesis (Simoneit and Philp, 1982). An example of an unaltered hydrocarbon fraction from a shallow sediment is shown in Figure $3 a$. The $n$-alkanes exhibit a strong odd carbon number predominance above $\mathrm{C}_{23}$, typical of higher plant wax, and a maximum at $C_{17}$ with no carbon number predominance below $\mathrm{C}_{20}$, typical of marine sources. Examples of typical $n$-alkane distributions are found in Figure 4.

The lipids of some of the shallower samples from Site 478 are derived from marine and terrigenous sources in approximately equal proportions (Table 2) (Simoneit and Philp, 1982; Galimov et al., 1982), whereas others are composed of dominantly terrigenous material (Rullkötter et al., 1982). The $\delta^{13}$ data for the total lipids indicate a marine origin (Galimov et al., 1982). As at Site 477, trace molecular markers in the lipids of shallow samples have distributions and configurations indicating a recent marine origin (Simoneit and Philp, 1982; Simoneit et al., 1984; Rullkötter et al., 1982).

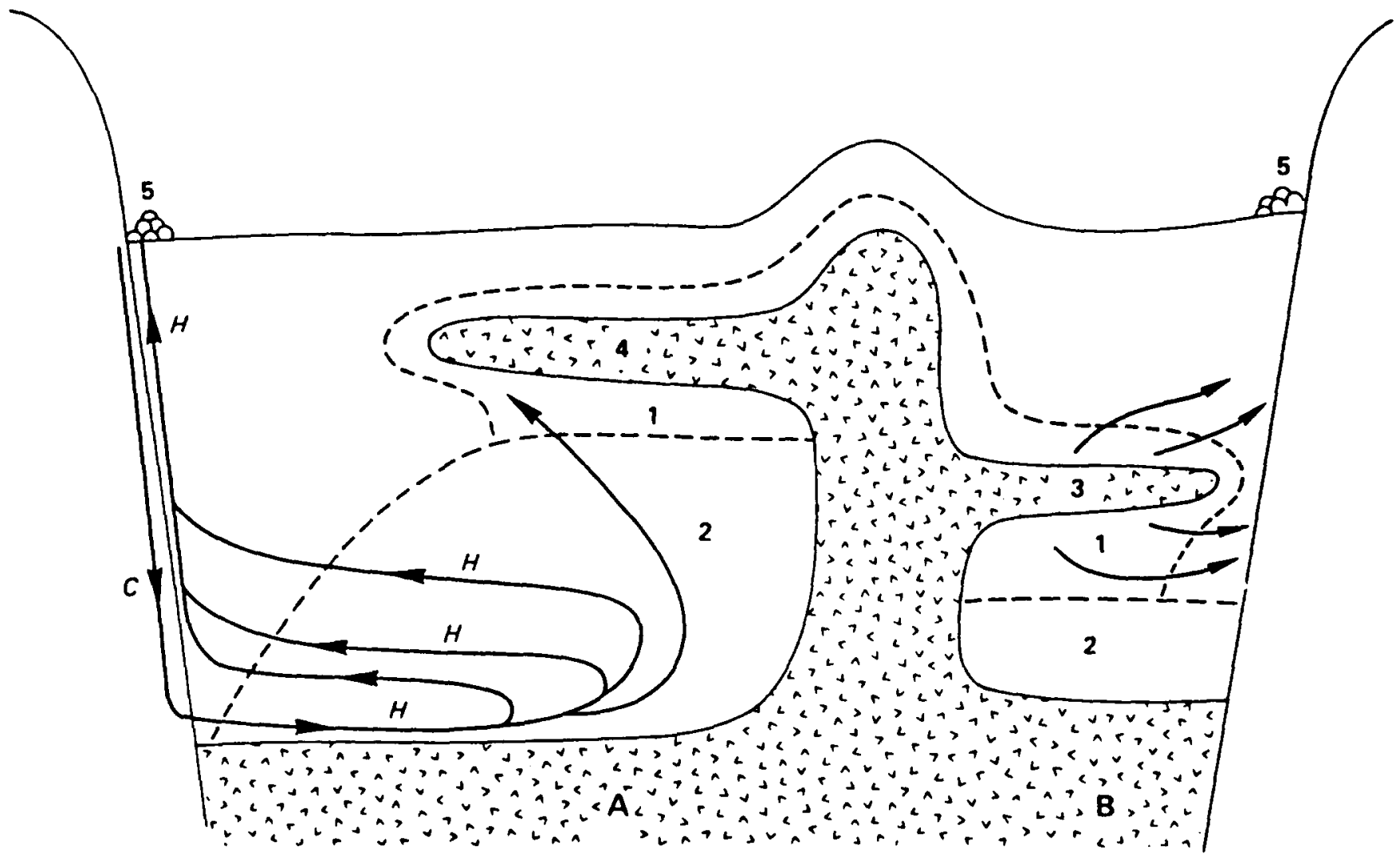

Figure 2 Schematic version of hydrothermal systems in Guaymas spreading centre associated with Sites 477 and 481 . (1) Porosities affected mostly by uppermost sill intrusions; (2) porosities affected by older dolerite intrusions and/or continued hydrothermal activity at greater depths; (3) sill intrusions of nature described for Site 481 (Einsele et al., 1980); (4) cooled sill (Site 477) acting as lid on deeper hydrothermal system; (5) hydrothermal deposits on basin floor: A, model for Site 477; B, model for Site 481. $\mathrm{H}=$ hot water advected through sediments and fault zones, $\mathrm{C}=$ cold water advected down through fault zones 
Hydrothermal alteration of organic matter: B. R. T. Simoneit et al.

Table 2 Sources of organic matter in unaltered sediments of Gulf of California

\begin{tabular}{|c|c|c|c|c|}
\hline & Interstitial gas & Lipids & Kerogen & References \\
\hline \multicolumn{5}{|l|}{ Guaymas Basin } \\
\hline \multicolumn{5}{|l|}{ Site 477} \\
\hline & - & terrigenous & marine & Galimov et al. (1982) \\
\hline & - & terrigenous/marine & marine & Simoneit and Philp (1982) \\
\hline & - & - & marine & Gilbert and Summerhayes (1982) \\
\hline & thermogenic/biogenic & - & - & Galimov and Simoneit (1982) \\
\hline \multicolumn{5}{|l|}{ Site 478} \\
\hline & - & terrigenous/marine & marine & Galimov et al. (1982) \\
\hline & - & terrigenous/marine & marine & Simoneit and Philp (1982) \\
\hline & - & terrigenous & - & Rullkötter et al. (1982) \\
\hline & - & - & marine/terrigenous & $\begin{array}{l}\text { Deroo et al. (1982); Kendrick (1982); } \\
\text { Gilbert and Summerhayes (1982) }\end{array}$ \\
\hline & biogenic & - & - & Galimov and Simoneit (1982) \\
\hline \multicolumn{5}{|l|}{ Site 481} \\
\hline & - & terrigenous/marine & marine & $\begin{array}{l}\text { Galimov et al. (1982); Simoneit and } \\
\text { Philp (1982) }\end{array}$ \\
\hline & - & terrigenous & terrigenous & Rullkötter et al. (1982) \\
\hline & - & marine & - & Thomson et al. (1982) \\
\hline & - & - & marine/terrigenous & $\begin{array}{l}\text { Deroo et al. (1982); Gilbert and } \\
\text { Summerhayes (1982) }\end{array}$ \\
\hline & biogenic/thermogenic & - & - & $\begin{array}{l}\text { Galimov and Simoneit (1982); Schoell } \\
\text { (1982); Whelan and Hunt (1982) }\end{array}$ \\
\hline \multirow{2}{*}{\multicolumn{5}{|c|}{$\begin{array}{l}\text { Guaymas Continental } \\
\text { Slope } \\
\text { Site } 479\end{array}$}} \\
\hline & & & & \\
\hline & - & marine/terrigenous & marine/terrigenous & $\begin{array}{l}\text { Galimov et al. (1982); Simoneit and } \\
\text { Philp (1982); Simoneit (1982) }\end{array}$ \\
\hline & - & terrigenous/marine & marine/terrigenous & Rullkötter et al. (1982) \\
\hline & . & - & marine/terrigenous & $\begin{array}{l}\text { Gilbert and Summerhayes (1982); } \\
\text { Kendrick (1982); Deroo et al. } \\
\text { (1982); Peters and Simoneit (1982) }\end{array}$ \\
\hline 0.000 & biogenic/thermogenic & - & - & $\begin{array}{l}\text { Simoneit and Galimov (1982); Whelan } \\
\text { and Hunt (1982); Simoneit (1982); } \\
\text { Curray et al. (1982) }\end{array}$ \\
\hline \multicolumn{5}{|r|}{ 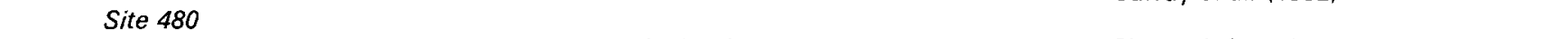 } \\
\hline & - & marine/terrigenous & - & Simoneit (1982) \\
\hline & - & - & marine/terrigenous & Peters and Simoneit (1982) \\
\hline & biogenic & - & - & Curray et al. (1982); Simoneit (1982) \\
\hline
\end{tabular}

At Site 481, the lipids in the shallow samples are dominated by terrigenous components (Table 2 and Figures $3 a$ and 4c) (Galimov et al., 1982; Rullkötter et al., 1982; Simoneit and Philp, 1982; Simoneit et al., 1984), except for one sample that has largely a marine origin (Thomson et al., 1982). This terrigenous influence is probably due to the proximity of continental sources, and the abundance of turbidites at this site. Again, the ${ }^{13} \mathrm{C}$ data for the total lipid fractions indicate an overall marine source (Galimov et al., 1982), which probably is due to the large amount of polar, marine material present in extracts from such recent sediments.

The kerogen fractions are made up of both marine and continental organic matter (Gilbert and Summerhayes, 1982). The main component is usually amorphous. Pyrolysis confirms this wide variation (Figure 5), some samples being classified as type II (probably marine), others as type III (probably terrigenous), and others as mixtures of both (Deroo et al., 1982; Rullkötter et al., 1982; Kendrick, 1982; Simoneit and Philp, 1982). The wide variations in organic facies result from the interplay of pelagic and turbidity current deposition. As also seen in lipid compositions, an increase in terrigenous character of the kerogen occurs from Site 477 through Site 481.

There is a wide range in total organic carbon (TOC, Figure 6), from about 0.3 to more than 3\% (Simoneit and Bode, 1982). The considerable variation in TOC with depth, especially at Site 481 , probably again represents the interplay between the pelagic sedimentation and turbidite deposition.

Carbon-to-nitrogen ratios $(\mathrm{C} / \mathrm{N})$ in Figure 6 range from 11 to 17 at most depths, but are higher near dolerite sills and where sediments contain other evidence of thermal alteration of organic matter. The $\mathrm{C} / \mathrm{N}$ values of unaltered sediments are similar to those found in Quaternary and Neogene oozes from beneath the Benguela upwelling zone (Meyers et al., 1983) and are close to the value of 12 reported by Ryther (1956) for modern marine sediments.

\section{Depositional environment}

Various indicators in the lipid fractions, for example pristane/phytane ratios of less than one, and the presence of perylene, pigments, and sulfur, suggest that depositional conditions were reducing (Didyk et al., 1978; Galimov et al., 1982; Simoneit and Philp, 1982). Although perylene is sometimes invoked as a terrigenous indicator (e.g. Rullkötter et al., 1982), it is a common constituent of DSDP Leg 63 sediments, which are dominated by marine organic matter (Louda and Baker, 1981; Rullkötter et al., 1981; Simoneit and Mazurek, 1981), and it is generally ubiquitous in recent sediments (Wakeham et al., 1979; LaFlamme and Hites, 1978; Hites et al., 1977;1980). The presence of perylene in a sediment more probably indicates 


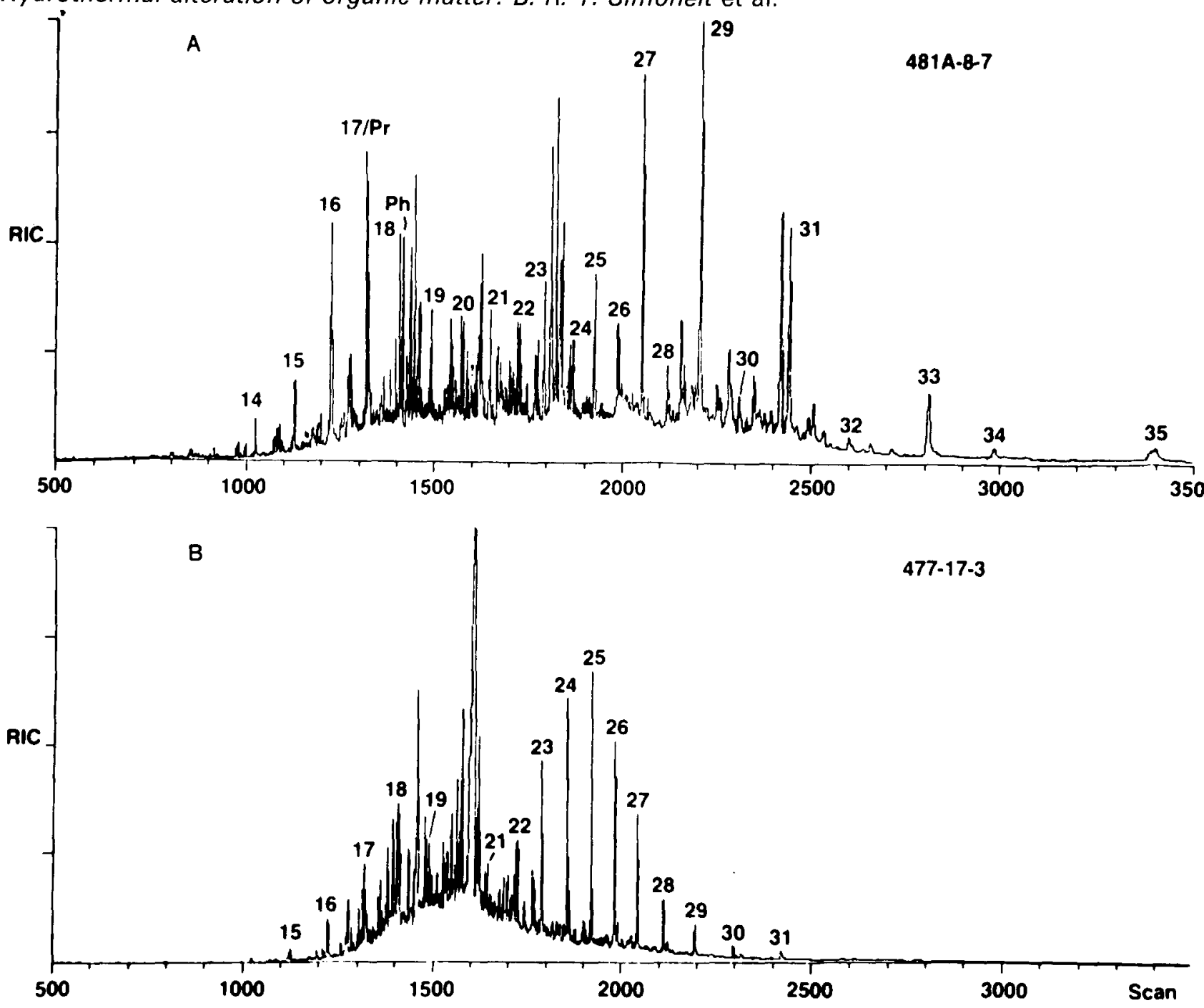

Figure 3 G.c.-m.s. total ion current traces for total hydrocarbon fractions from (a) an unaltered, immature sample and (b) a thermally altered sample of sediments from the Guaymas Basin. Number of carbon atoms in n-alkanes are labelled, and pristane and phytane are indicated by $\mathrm{Pr}$ and $\mathrm{Ph}$, respectively

deposition under anoxic conditions, where it may form from precursors of either terrigenous or marine origin (Simoneit and Mazurek, 1981). Because these Guaymas Basin sediments are not laminated and because there is a tendency toward an exponential decline in TOC beneath the sediment-water interface, it seems unlikely that the bottom waters are themselves anoxic. Furthermore, Calvert (1964) reports that bottom waters in the Guaymas Basin contain up to about $1 \mathrm{ml} / \mathrm{l} \mathrm{O}_{2}$. These different lines of evidence suggest that the anoxic conditions which have influenced the lipid fractions prevail at or beneath the sediment-water interface and are not a feature of the overlying bottom water.

\section{Alteration of organic matter}

Various lipids undergo diagenetic alteration in the shallow sequences. At greater depths they experience more rapid diagenesis under the influence of thermal stress (Galimov et al., 1982; Baker and Louda, 1982; Thomson et al., 1982; Simoneit and Philp, 1982; Simoneit et al., 1984). Total organic matter tends to decrease exponentially with depth (Figure 7), which could be attributed to diagenesis involving microbial degradation of labile organic matter. Viable methanogenic bacteria are present in the uppermost sediments (Oremland et al., 1982), but they normally comprise only a part of the total microbial population.

The general effects of thermal stress imposed on the organic matter by the various sill intrusions and high heat flow are greatest at Site 477 , intermediate at Site 481, and lowest at Site 478 . At Site 477 the interstitial gas contained only a limited range of hydrocarbons and large amounts of $\mathrm{CO}_{2}$ and $\mathrm{H}_{2} \mathrm{~S}$ (Curray et al., 1982; Simoneit, 1982a). Methane, ethane, benzene, and toluene dominate the light hydrocarbons, indicating higher temperature thermogenesis (Whelan and Hunt, 1982). Thermogenesis is confirmed by the methane $\delta^{13} \mathrm{C}$ values between -40 and $-65 \%$ (Galimov and Simoneit, 1982a, b; Simoneit and Galimov, 1984) which are summarized in Figure 8 . The highest thermal stress is evident at Site 477 followed by Site 481 .

At Site 478 there is no sign of major thermal stress from the upper sill intrusions in the interstitial gas data, and there was no thermogenic $\mathrm{H}_{2} \mathrm{~S}$ at depth (Curray et al., 1982; Simoneit, 1982a). The $\delta^{13} \mathrm{C}$ data for methane suggest that thermogenic methane increases with depth (Figure 8; Galimov and Simoneit, 1982a, b; Simoneit and Galimov, 1984). The minimal influence of the shallow sill intrusion is confirmed by the gasoline range of hydrocarbon data (Whelan and Hunt, 1982), which 
Hydrothermal alteration of organic matter: B. R. T. Simoneit et al.
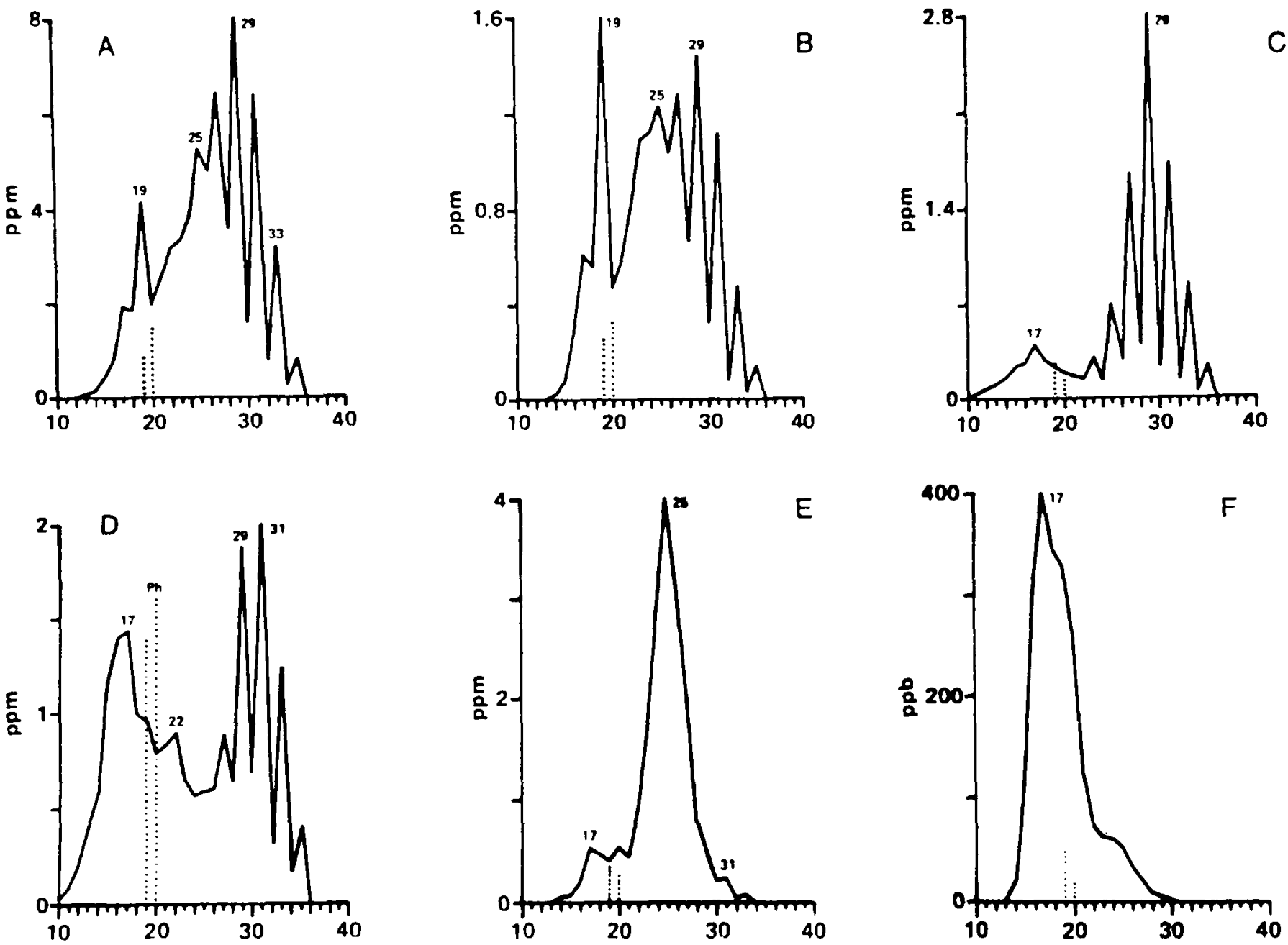

Figure 4 Distributions of $n$-alkanes (solid lines) and pristane and phytane (dotted lines) in unaltered (a,b,c,d) and hydrothermally altered (e,f) sediments in the Guaymas Basin.

(a) Sample 477-5-1, 81-91 cm; (b) Sections 478-2-2, 2-3, 2-6, and 3-1 (composited); (c) Sample 481A-6-5, 118-120 cm; (d) Sample 479-29-5, 114-116 cm; (e) Sample 477-22-1, 26-28 cm; (f) Sample 478-29-2, 129-131 cm

lack unusual concentrations of ethane or aromatic hydrocarbons.

At Site 481, the interstitial gas data are more complicated, but do show a strong thermogenic influence. The $\mathrm{C}_{3}-\mathrm{C}_{5}$ hydrocarbon distributions above the upper sill complex exhibit a triple maximum that is not as well developed for methane and ethane (Simoneit, 1982a; Einsele et al., 1980; Galimov and Simoneit, 1982a,b; Simoneit and Galimov, 1984). The $\delta^{13} \mathrm{C}$ data for methane suggest an admixture of thermogenic and biogenic gas, with the thermogenic component increasing with depth (Figure 7) (Galimov and Simoneit, 1982a, b; Simoneit and Galimov, 1984). Thermogenic $\mathrm{H}_{2} \mathrm{~S}$ was not detected at this site. The multiple maximum for the $C_{3}-C_{5}$ hydrocarbons was not detected in the gasoline range hydrocarbons desorbed from frozen core samples, but there was a general increase in the $\mathrm{C}_{5}-\mathrm{C}_{8}$ hydrocarbons above the sill complex (Whelan and Hunt, 1982).

The bitumen fractions of sedimentary organic matter from near the intrusions display significant alteration by thermal stress. This effect is most dramatic at Site 477 , where the proportion of extractable lipids in the total organic matter increases towards the sill, then decreases with increasing depth below it, indicating severe alteration (Galimov et al., 1982). With increasing thermal stress the chlorins are first converted to metalloporphyrıns and then destroyed at very high temperatures (Galimov et al., 1982; Louda and Baker, 1982). In samples located close to the sill, the hydrocarbon distributions resemble those of petroleum (e.g. Figures $3 b$ and $4 e, f$ ), with smaller amounts of $n$-alkanes larger than $C_{27}$ compared to samples from shallower depths, and a CPI (carbon preference index) of about 1.0 (Simoneit and Philp, 1982; Simoneit et al., 1984). These samples, and equivalent samples from Site 481 , contain major amounts of terminal olefins (Simoneit and Philp, 1982), which are stable for only short periods and are generated by pyrolytic processes (Hoering, 1977). These compounds suggest that significant thermal stress occurred very recently. In addition to the above evidence, steroid and triterpenoid compounds have mature configurations, and their distributions indicate thermal stress. These compounds are almost completely destroyed in the deepest samples from Site 477 (Simoneit and Philp, 1982; Simoneit et al., 1984).

The lipids of samples from Site 478 have experienced a milder thermal history. Their $n$-alkane patterns are essentially unaltered, except very close to sill intrusions (Galimov et al., 1982; Simoneit and Philp, 1982; Rullkötter et al., 1982; Simoneit et al., 1984). The pattern of total hydrocarbon yields versus depth suggests the onset of maturation has been reached 


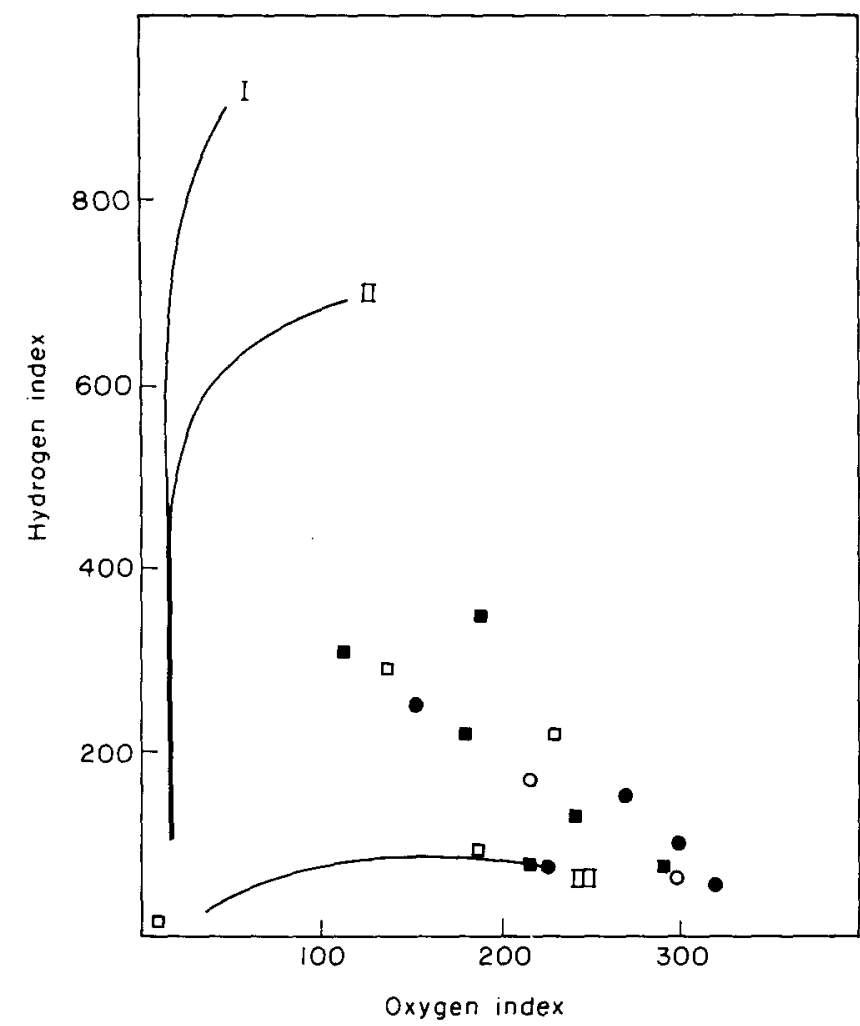

Figure 5 Rock-Eval van Krevelan-type plots for samples from Sites 478 and 481 in the Guaymas Basin. Data are from ( $\square$ ); ( $\square$ ) Deroo et al. (1982) and (O); (O) Rullkötter et al. (1982). Hydrogen index units are $\mathrm{mg} \mathrm{HC} / \mathrm{g}$ organic carbon and oxygen index units are $\mathrm{mg} \mathrm{CO} / \mathrm{g}$ organic carbon

between the upper sills (Galimov et al., 1982), and is enhanced near sill contacts (e.g. Figure 4f) (Simoneit and Philp, 1982).

At Site 481, the lipids have been exposed to greater thermal stress than at Site 478, but less than at Site 477 . The $n$-alkanes have an essentially unaltered distribution, except close to sills, where thermal products become more dominant (Rullkötter et al., 1982; Galimov et al., 1982; Simoneit and Philp, 1982; Simoneit et al., 1984). Total hydrocarbon contents increase relative to TOC close to sills (Galimov et al.,
1982; Simoneit and Philp, 1982). Steroid and triterpenoid residues also show the effects of maturation from thermal stress near sills (Simoneit and Philp, 1982; Simoneit et al., 1984), and as in the highly altered samples from Site 477 , terminal olefins are found in samples that are severely thermally stressed, indicating a high degree of recent heating from sill intrusions (Simoneit and Philp, 1982).

The kerogen data confirm that thermal alteration is greatest at Site 477 (Gilbert and Summerhayes, 1982; Jenden et al., 1982). Although the section above the main sill (at $58 \mathrm{~m}$ ) is immature, the section below that sill has a thermal alteration index of $2+$, equivalent to a vitrinite reflectance value $R_{0}$ of $0.7-0.9 \%$, and is probably in the oil window (Dow, 1977). As the sill is approached, maturation increases to a thermal alteration index of $3\left(\mathrm{R}_{\mathrm{o}}\right.$ equivalent is about $1.2 \%$, near the bottom of the oil window, Dow, 1977); this degree of maturation occurs $15 \mathrm{~m}$ below the sill, and implies that the sediments nearer to the sill have been baked and have thus lost their potential to generate liquid hydrocarbons (Gilbert and Summerhayes, 1982).

Curie Point pyrolysis-GC (Cupy-GC) data for kerogens of samples taken near the sill reflect the effects of this thermal stress (Simoneit and Philp, 1982; Simoneit et al., 1984). Examples of pyrograms of an unaltered kerogen and an altered kerogen are shown in Figure 8 . The pyrolysis yields drop dramatically, and the products shift from higher to lower molecular weight ranges. The organic matter at depth was microscopically described by Rueda-Gaxiola et al., (1982) as coaly and highly altered. The atomic $\mathrm{N} / \mathrm{C}$, carbon isotope composition, and electron spin resonance (e.s.r.) spin density of the kerogens all demonstrate thermal alterations near the sill contact (Jenden et al., 1982).

At Site 478 , both the vitrinite reflectance $\left(R_{o}\right)$ (Rullkötter et al., 1982) and the thermal alteration indices (Gilbert and Summerhayes, 1982) show that the section is generally immature, except possibly near the sills. A downhole increase in $\mathrm{R}_{\mathrm{o}}$ values to $0.37 \%$ at about $250 \mathrm{~m}$ (Rullkötter et al., 1982) suggests that this is a hot area (heat flow is $3.65 \mathrm{HFU}$ according to

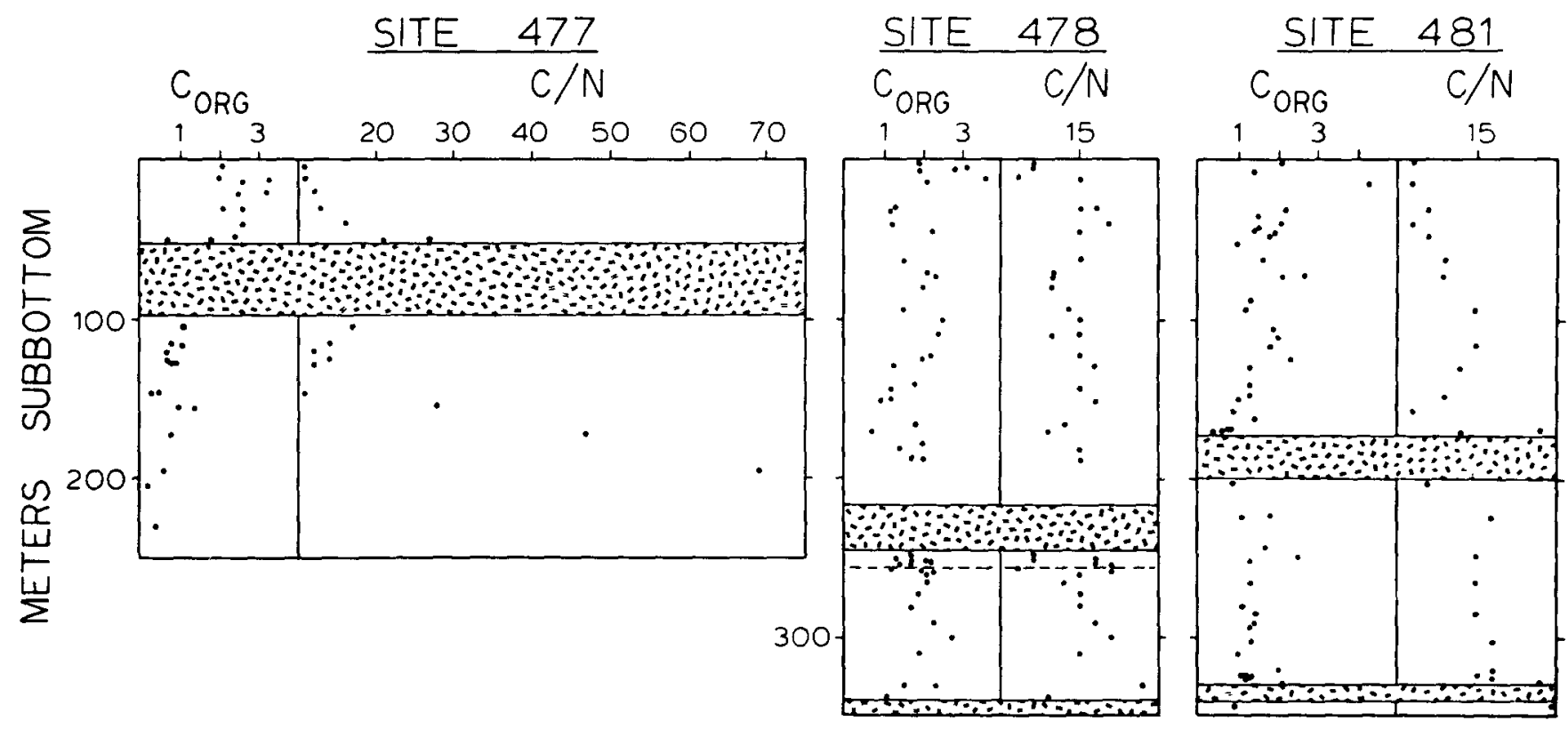

Figure 6 Downhole plots of organic carbon concentrations and of organic matter atomic C/N ratios in samples from Sites 477,478 , and 481 in the Guaymas Basin. Data from Simoneit and Bode (1982) 


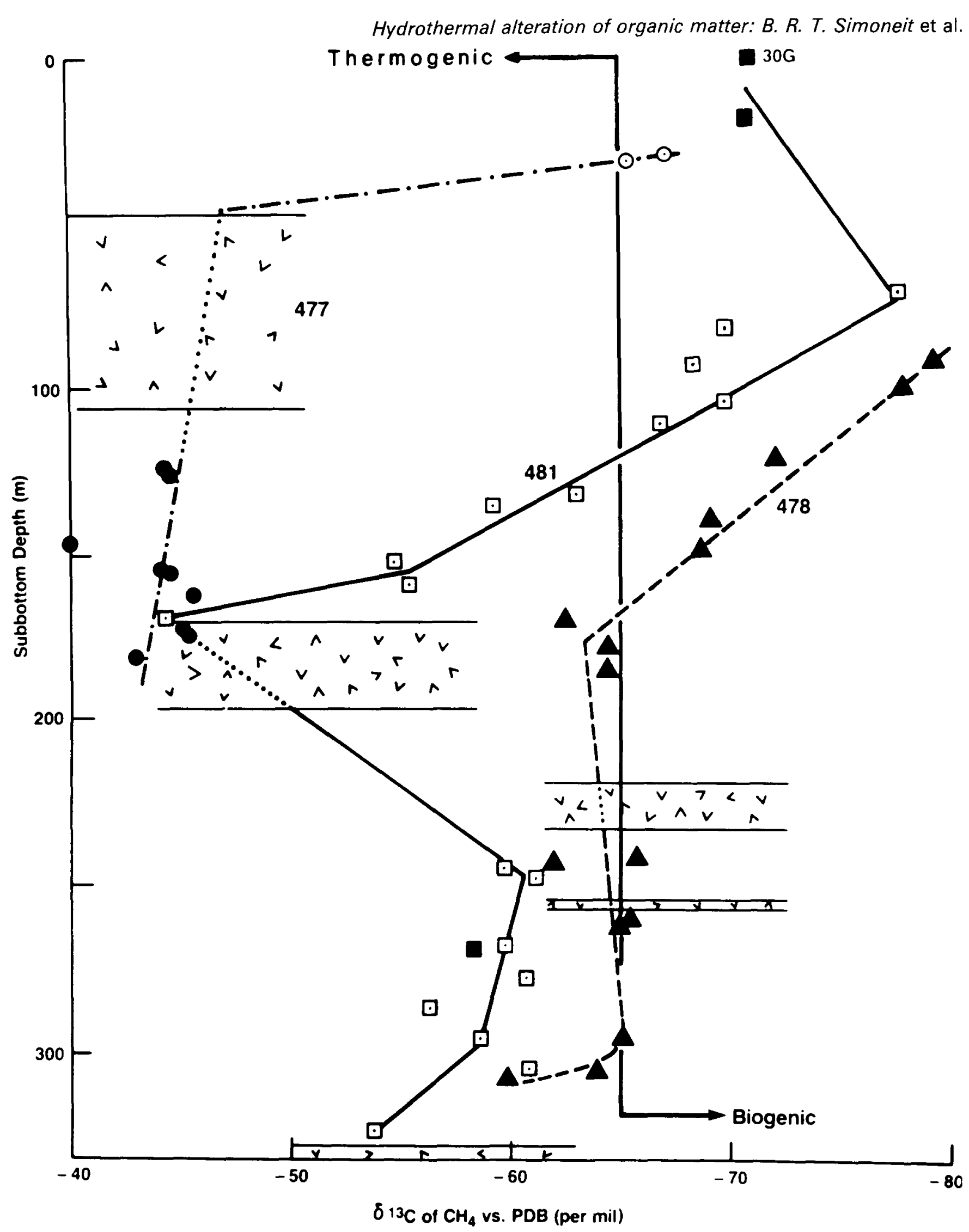

Figure 7 Trends of carbon-13 depletion versus depth in interstitial methane at DSDP Sites 477,478 , and $481\left(\delta^{13} \mathrm{C}\right.$ data reported versus PDB standard). Dolerite intrusions are indicated at the appropriate depth for each site. Circular data points are for Site 477 , square data points for Site 481 (solid squares for canned samples and $30 \mathrm{G}$, Simoneit et al., 1979), and triangular data points for Site 478

Einsele et al. , 1980). The top of the oil window may be as shallow as $450-550 \mathrm{~m}$. As the sill at $340 \mathrm{~m}$ is approached, the thermal alteration index rises to $2+$ ( $R_{o}$ approx. $0.7-0.9 \%$ ), probably in response to the intrusion (Gilbert and Summerhayes, 1982).

The Cupy-GC data for kerogen samples taken at depth and on either side of a sill intrusion of Site 478 clearly show the effects of thermal stress. Amounts of pyrolysate decrease, and the molecular distributions are different, compared with unaltered samples (see Figure 8) (Simoneit and Philp, 1982; Simoneit et al., 1984). The kerogens from Site 478 near the sill reflect 
Hydrothermal alteration of organic matter: B. R. T. Simoneit et al.

0
0
$c$
0
0
0
0
0
0
2
0
0
0
0
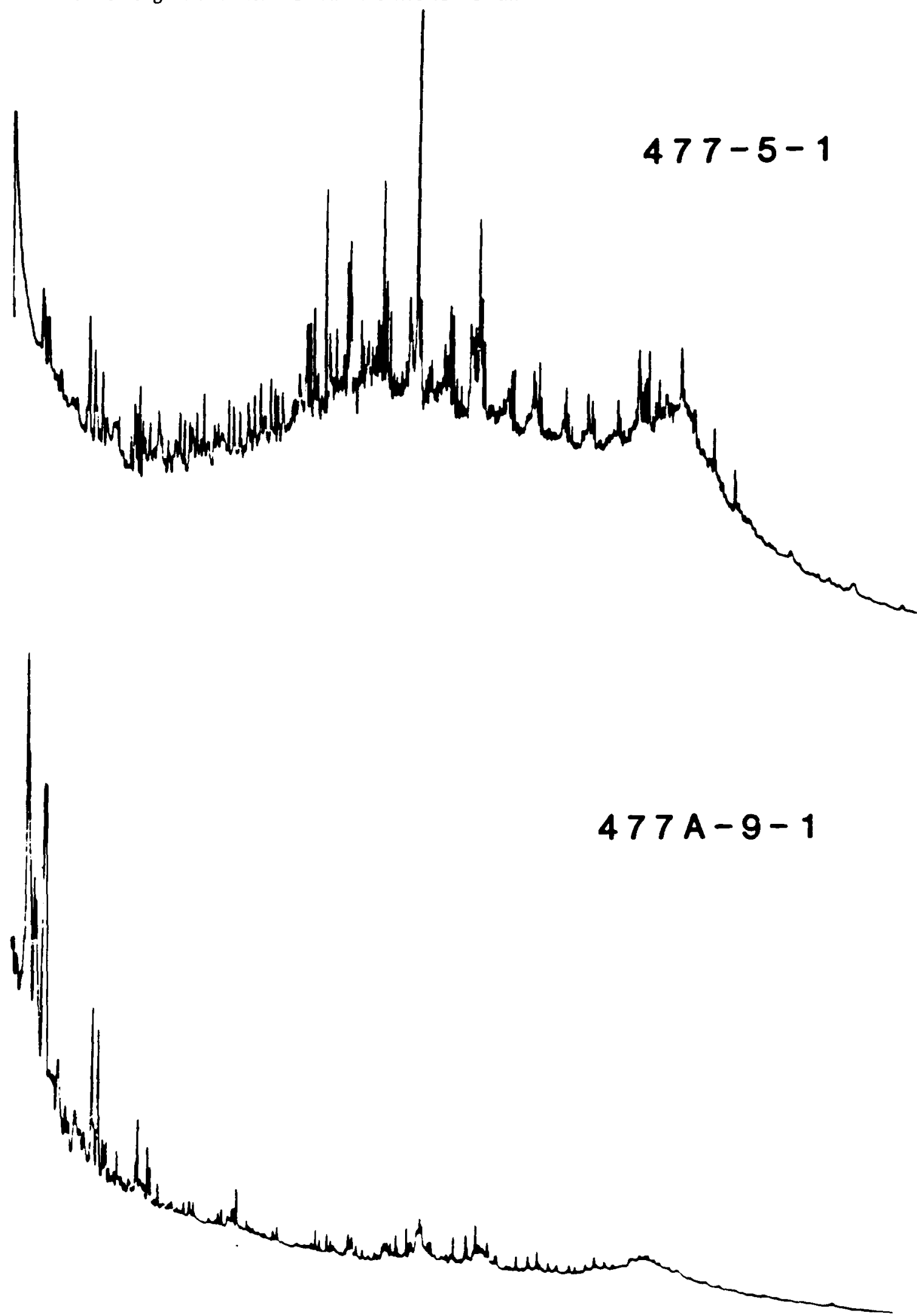

\section{Time}

Figure 8 Examples of Curie point pyrolysis-gas chromatography traces from kerogen from unaltered (top) and hydrothermally altered (bottom) sediments from Site 477 in the Guaymas Basin. Respective sub-bottom depths of these two samples are $30 \# \mathrm{~m}$ and $240 \# \mathrm{~m}$ (from Simoneit and Philp, 1982) 
Hydrothermal alteration of organic matter: B. R. T. Simoneit et al.

the thermal stress least of the three Guaymas Basin sites. The e.s.r. spin density shows a lesser maximum at higher $\mathrm{H} / \mathrm{C}$ values than for Sites 477 and 481 (Jenden et al., 1982). Microscopic examination of organic matter by Rueda-Gaxiola et al., (1982) confirms that the kerogen has been altered near sills.

At Site 481 , which may be a 'hot' hole with up to 4 HFU (Einsele et al., 1980), the vitrinite reflectance data (Rullkötter et al., 1982) and thermal alteration indices (Gilbert and Summerhayes, 1982) suggest that the section is immature down to $280 \mathrm{~m}$. As the sills at $160 \mathrm{~m}$ and at $330 \mathrm{~m}$ are approached, there is a slight increase in the thermal alteration index (Gilbert and Summerhayes, 1982).

The Cupy-GC data for kerogens from the upper sill complex reflect the thermal stress in showing a decrease in pyrolysis products with increasing proximity to sills (Simoneit and Philp, 1982; Simoneit et al., 1984). However, one sample from close to the sill did have a significant amount of pyrolysate; this may be a 'bituminized kerogen' of the type described from DSDP Site 368 off West Africa (Peters et al., 1978), where igneous intrusions also penetrate sediments. The Cupy-GC trace for a sample from $233 \mathrm{~m}$ sub-bottom showed an essentially unaltered pattern (Simoneit and Philp, 1982; Simoneit et al., 1984), confirming the results of vitrinite and thermal alteration index analyses.

\section{Gases and light gasolines}

Thermogenic gas was found in sediments from Sites 477 and 481 (Simoneit, 1982a; Galimov and Simoneit, 1982a, b; Gilbert and Summerhayes, 1982; Simoneit and Galimov, 1984). The thermogenic gas contribution increases downhole toward the sill at Site 477 , and is very high below the sill (Simoneit and Galimov, 1982a, b; Simoneit and Galimov, 1984). The same is observed in the analyses of light hydrocarbons, which increase toward the sill, and are most abundant beneath the sill (Whelan and Hunt, 1982). These various data suggest that gas and light gasoline range components may be migrating up into the subsill section.

At Site 478 , ethane shows a slight increase with depth toward the shallow sill at $200-250 \mathrm{~m}$, then a decrease, followed by an increase toward the deeper sill at $350 \mathrm{~m}$ (Simoneit, 1982a; Galimov and Simoneit, 1982a, b). The immaturity of the sedimentary section is confirmed by the downhole change in the $\delta^{13} \mathrm{C}$ values of methane, from $-80 \%$ (biogenic) at the surface, to $-60 \%$ (slight thermogenic input) at depth (Figure 8 ) (Galimov and Simoneit, 1982a, b; Simoneit and Galimov, 1984). Gilbert and Summerhayes (1982) also interpret the gas to biogenic rather than thermogenic and Whelan and Hunt (1982) confirm that thermal stress has had little influence on the light hydrocarbons at this site.

At Site 481 , the $C_{2} / C_{1}$ ratio increases, and the $\delta^{13} \mathrm{C}$ value of methane decreases in response to thermal stress from the sills (Figure 8; Simoneit, 1982a; Galimov and Simoneit, 1982a, b; Gilbert and Summerhayes, 1982; and Schoell, 1982). Between the sills there is evidence for only mild thermal alteration $\left(\delta^{13} \mathrm{C}\right.$ of methane $\mathrm{ca} .-60^{\circ} \%$; Schoell, 1982; Galimov and Simoneit, 1982a, b; Simoneit and Galimov, 1984), and the same is indicated by the light gasoline range data (Whelan and Hunt, 1982).

\section{Migration}

Migration of gases and of certain lipid components has occurred as a result of the high thermal gradients in the Guaymas Basin. Migration of interstitial gas into shallow sediments was recognized in a gravity core (30G) near Site 481 prior to Leg 64 (Simoneit et al., 1979). Simple fluorescence measurements show that bitumens (lipids) have migrated away from sill intrusions at Sites 478 and 481 (Simoneit, 1982a), and this migration has been confirmed by analysis (Galimov et al., 1982; Simoneit and Philp, 1982; Simoneit et al., 1984). The approximate distances of upward and downward migration from intrusions in these unconsolidated sediments is about the same as observed in lithified Cretaceous black shales from Site 368 in the Cape Verde Basin whicin were intruded by diorite in the Miocene (Simoneit et al., 1978, 1981). Subsequent data show that lipid products from thermogenic processes at depth (petroleum) are brought to the seabed by hydrothermal circulation. The less volatile and less soluble components condense at the seafloor as oil in mound-like mineral deposits with hydrothermal vents (Simoneit and Lonsdale, 1982; Simoneit, 1983a,c; 1984; 1985; Simoneit and Kawka, 1986)

Residual carbon remaining in the sediment (spent kerogen after liquid hydrocarbon generation) was detected at Sites 477 and 478 (Curray et al., 1982; Simoneit, 1982a). It consists of fine-grained amorphous carbon with adsorbed interstitial gas and traces of adsorbed bitumen residues (Simoneit, 1982a; Simoneit and Philp, 1982; Simoneit et al. . 1984).

\section{Guaymas Slope, Sites 479 and 480}

Sites 479 and 480 are situated on the Mexican continental slope almost due north of the Guaymas Basin (Figure 1), and contain laminated sediments (Table 1) (Curray et al., 1982; Schrader et al., 1980). Laminated diatomaceous sediments are deposited on the upper continental slope throughout the Northern Gulf of California, wherever the oxygen minimum zone contains less than $0.2 \mathrm{ml} / \mathrm{l} \quad \mathrm{O}_{2}$ (Calvert, 1964). Alternations of laminae rich in diatoms with those rich in terrigenous clay apparently reflect seasonal variations in productivity or runoff, or some combination of these (Calvert, 1964; Schrader et al., 1980). Lamination, then, is a response to both source variations (marine versus terrigenous input) and preservation (a reducing, or anoxic water column prevents significant bioturbation and favors preservation of organic matter as well as laminations).

Drilling disturbed the sediments at Site 479 , making it difficult to ascertain whether the first $200 \mathrm{~m}$ of diatomaceous ooze were laminated or not. At Site 480 , which is about $6 \mathrm{~km}$ from Site 479 , a $150 \mathrm{~m}$ long hydraulic piston core was successfully obtained, consisting of an undisturbed, laminated sediment column thought to be equivalent in age to the upper section from Site 479 . In the Site 480 core laminated zones alternate with homogeneous zones that are bioturbated at least in places. The deeper sections at Site 479 are more indurated than the shallow sections and thus were less disturbed by drilling. Laminated sediments continue to the bottom of this hole, but in Unit 3 (below $365 \mathrm{~m}$ sub-buttom) nannofossils and 
Hydrothermal alteration of organic matter: B. R. T. Simoneit et al.

diatoms virtually disappear, suggesting a major paleoenvironmental change.

Changes from laminated to homogenous sediments are thought to represent changes from times of more productive surface water with a high flux of organic matter, thereby increasing the anoxicity of bottom water in the oxygen minimum zone. The former times are thought to correspond to glacial periods, when winds were more consistently northerly and drier, and upwelling currents were correspondingly strong, whereas the latter times correspond to interglacials, when winds were southeasterly and wet, and upwelling currents were less pronounced (Schrader, 1982; Schrader and Baumgartner, 1983).

Because of the combination of a high rate of supply of organic matter (through high productivity caused by upwelling) and ideal conditions for preserving it (through the low oxygen concentrations in the oxygen minimum zone), the sediments of the upper continental slope are rich in organic matter - usually with TOC values of $2-4 \%$ (Figure 9 ).

\section{Sources of organic matter}

Marine-derived organic matter dominates the section at Sites 479 (Units 1 and 2) and 480 (Table 2). Microscopic analyses show that much of this material is present as liptinitic amorphous organic matter, with some as algal remains (Rullkötter et al., 1982; Gilbert and Summerhayes, 1982; Kendrick, 1982; and Deroo et al., 1982). There are substantial minor terrigenous components in some samples, consisting of admixed structured terrestrial materials and coaly material or inertinite.

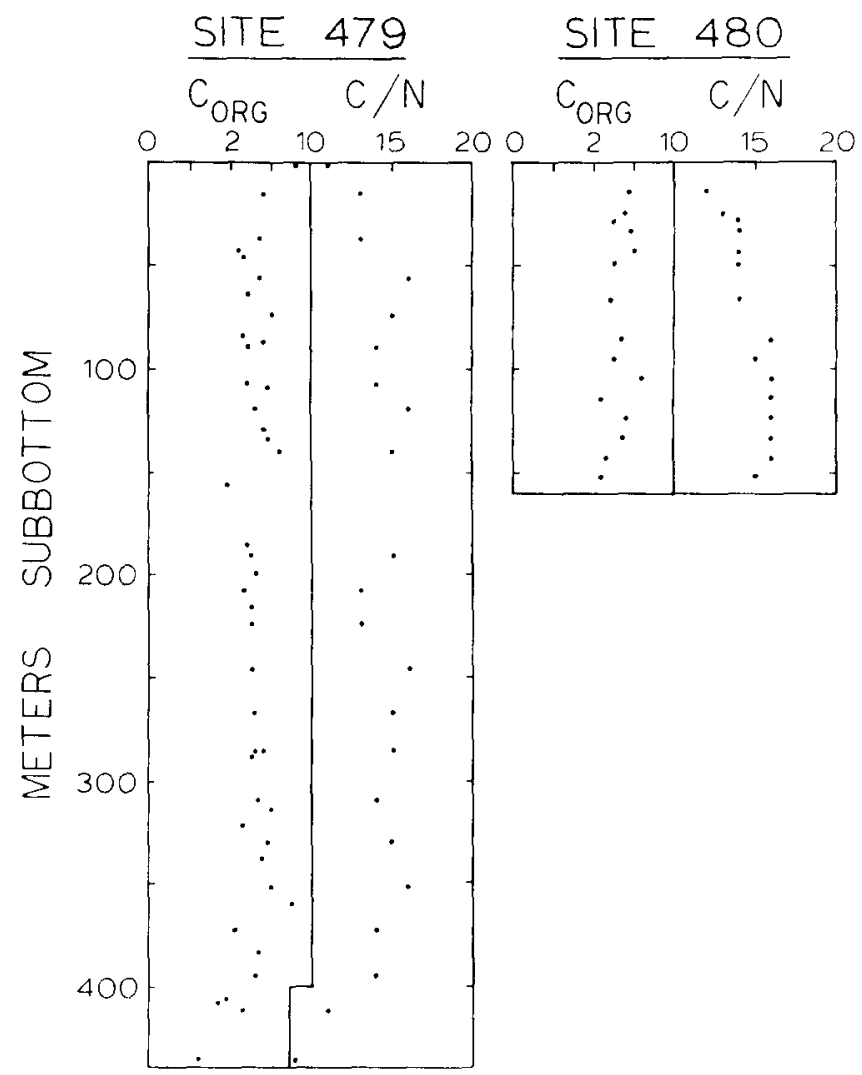

Figure 9 Downhole plots of organic carbon concentrations and of organic matter atomic $\mathrm{C} / \mathrm{N}$ ratios in samples from Sites 479 and 480 on the Guaymas continental slope. Data from Simoneit and Bode (1982)
The mixed nature of the sedimentary organic matter is confirmed by isotopic analyses, lipid analyses, and pyrolyses. Long chain terrigenous plant waxes dominate the $n$-alkane distributions of the lipid extracts, probably because the large marine component of the sediment contains few $n$-alkanes. Rock-Eval pyrolysis confirms that the organic matter consists mostly of type II (marine) organic matter, or of mixtures of types II (marine) and III (terrigenous) organic matter (Figure 10), (Deroo et al., 1982). This interpretation is confirmed by elemental analyses of kerogen isolated from the samples; $\mathrm{H} / \mathrm{C}$ ratios average 1.18 in Units 1 and 2 at Site 479 (Deroo et al., 1982 Peters and Simoneit, 1982; and Kendrick, 1982) and 1.15 at Site 480 (Peters and Simoneit, 1982).

Unit 3, at the base of Hole 479, has a different organic facies; most of its organic matter appears to be land-derived. Rock-Eval pyrolysis data show that samples from this unit consist almost entirely of type III organic matter (Rullkötter et al., 1982; Deroo et al., 1982; Peters and Simoneit, 1982). The $\mathrm{H} / \mathrm{C}$ ratios of kerogens of this unit are lower than those in Units 1 and 2 , suggesting a greater terrigenous influence, which is confirmed by isotopic data (Galimov et al., 1982).

\section{Preservation of organic matter}

The concentration of organic carbon seems to be controlled by the supply and preservation of marine organic matter. Samples having a higher content of marine or marine-derived amorphous organic matter also have higher TOC values (Figure 11). Sediments with low TOC's, such as those in Unit 3 at the base of Site 479 (Figure 9), usually are dominated by terrigenous organic matter (Figure 12). This applies not only at Sites 479 and 480 , but also at the other sites in the Gulf of California (Figure 11). Furthermore, there

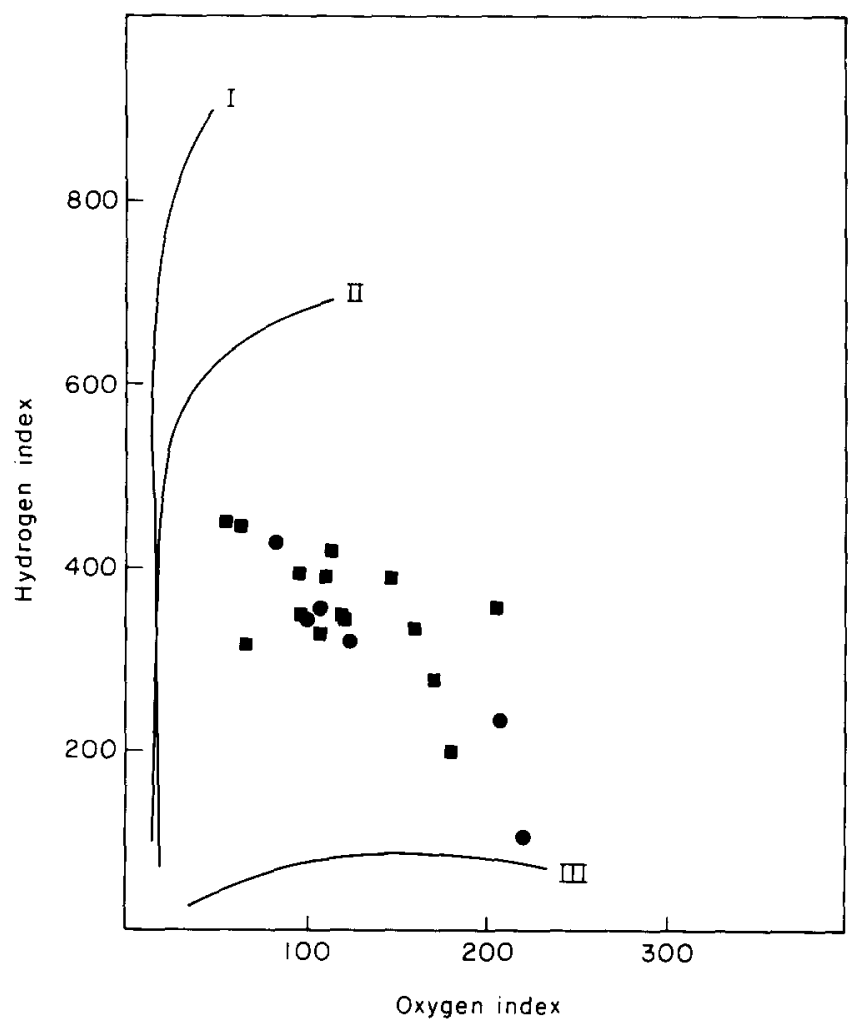

Figure 10 Rock-Eval van Krevelen-type plots for samples from Site 479 on the Guaymas continental slope. Data from Deroo et al. (1982) and Rullkötter et al. (1982). Units same as in Figure 5 
Hydrothermal alteration of organic matter: B. R. T. Simoneit et al.

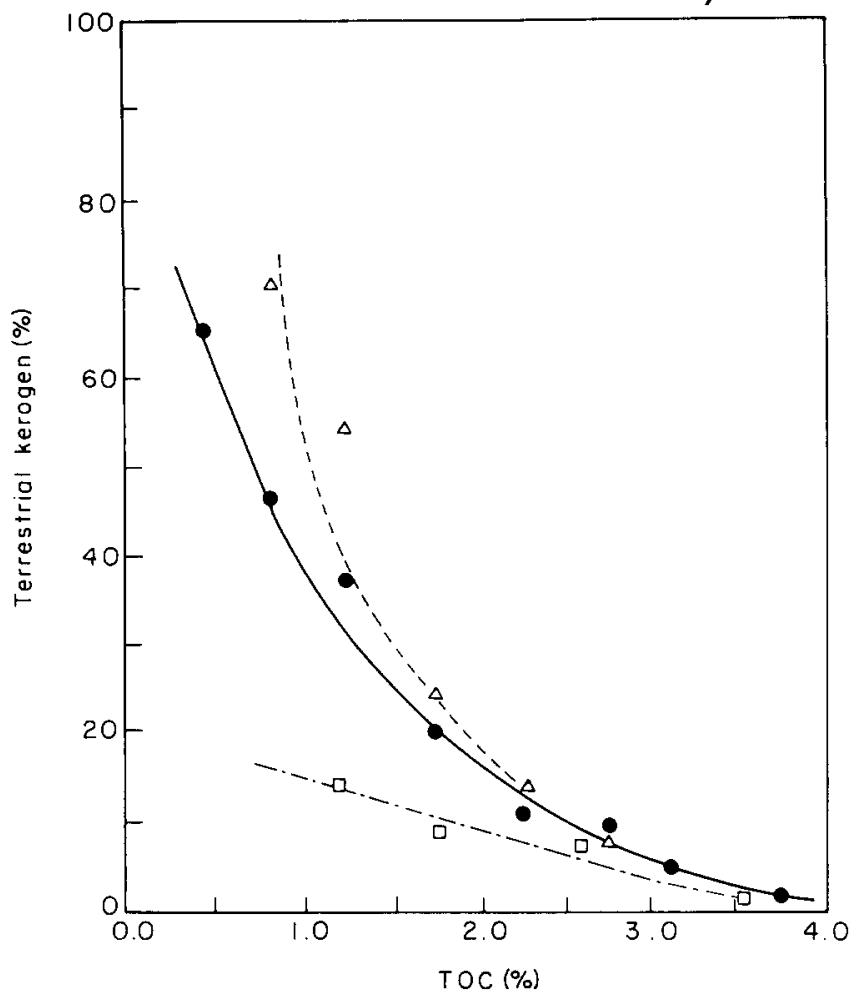

Figure 11 Interdependence of TOC and organic matter type in productive Guaymas Basin sites and in less productive Cabo San Lucas sites. Data from Gilbert and Summerhayes (1982). See Figure 1 for general locations. Preservation of marine amorphous material dilutes terrigenous organic matter and increases TOC (from Simoneit et al., 1982). ( $\square$ ) Cabo San Lucas; $(\triangle)$ Guaymas Basin and Slope; (O) all sites

is a correlation between high TOC values and high hydrogen indices in samples from Site 479 (Peters and Simoneit, 1982; Kendrick, 1982; Simoneit, 1982b; $1983 \mathrm{~b}$ ). This, again, suggests that the preservation of lipid-rich marine organic matter results in high TOC, as observed in other environments (Summerhayes, 1981).

\section{Alteration}

Diagenesis by sulphate-reducing bacteria is one possible explanation for the exponential decrease in TOC from the surface (3.6\% TOC) to a depth of $30-40$ $\mathrm{m}(2.5 \%$ TOC) at Site 479 (Figure 9). An exponential decrease of sulphate from the surface $(30 \mathrm{mM})$ to about $10 \mathrm{~m}$ sub-bottom $(3 \mathrm{mM})$ is also observed at this site (Gieskes et al., 1982b), which indicates that sulphate reduction is essentially complete below that depth. However, the decrease in TOC is accompanied by a change from laminated (surface) to homogenous (subsurface) sediments in the contemporaneous sediments of Site 480; therefore, it may instead reflect TOC preservation at time of deposition, rather than diagenetic change. Because the oxygen minimum zone impinges upon the bottom at Sites 479 and 480 , microbially-mediated diagenesis has probably been restricted by the lack of oxygen. This factor may explain why the average TOC at Sites 479 and 480 (about 2.5\%) is much higher than at the other sites in the Gulf of California.

$\mathrm{C} / \mathrm{N}$ ratios do not change significantly with depth (Simoneit, 1982a; Simoneit and Bode, 1982), suggesting that diagenetic changes may not be very important. However, there is evidence for early thermal generation of hydrocarbons with depth at Site 479 ; therefore, the $\mathrm{C} / \mathrm{N}$ ratio may not be a good indicator of downhole changes in organic matter, except under extremely high thermal stress such as Site 477. The entire section of Site 479 is thermally immature. Vitrinite reflectance $\left(R_{o}\right)$ values increase gradually downhole to a maximum of $0.38 \%$ (Figure 12; Kendrick, 1982; Rullkötter et al., 1982; and Peters and Simoneit, 1982).

Other indications of immaturity are: (1) the absence of free hydrocarbons in pyrolysis analyses (Peters and Simoneit, 1982); (2) low $\mathrm{T}_{\max }$ measured during pyrolysis (Peters and Simoneit, 1982); (3) unaltered appearance of $n$-alkanes as deep as $395 \mathrm{~m}$ sub-bottom (where there is also a high CPI - Galimov et al., 1982); (4) unaltered $\delta^{13} \mathrm{C}$ isotope pattern in separated bitumen fractions deep in the hole (Galimov et al., 1982); (5) lack of downhole increase in extractable bitumens relative to TOC (Rullkötter et al., 1982); and (6) immature molecular markers in lipids (Simoneit, 1982b; 1983b).

Nontheless, there is some evidence of thermal alteration in the sediments of Site 479 . For example, there is a moderate increase in the ratio of hydrocarbons to TOC in Section 479-43-1 at $395 \mathrm{~m}$ sub-bottom (Galimov et al., 1982). Such generation of hydrocarbons with increasing depth is most apparent in the shipboard interstitial gas data, in which ethane increases dramatically below $280 \mathrm{~m}$ sub-bottom, and propane and iso-butane have maximum concentrations at $400 \mathrm{~m}$ sub-bottom (Curray et al., 1982). The $\mathrm{C}_{2}-\mathrm{C}_{8}$

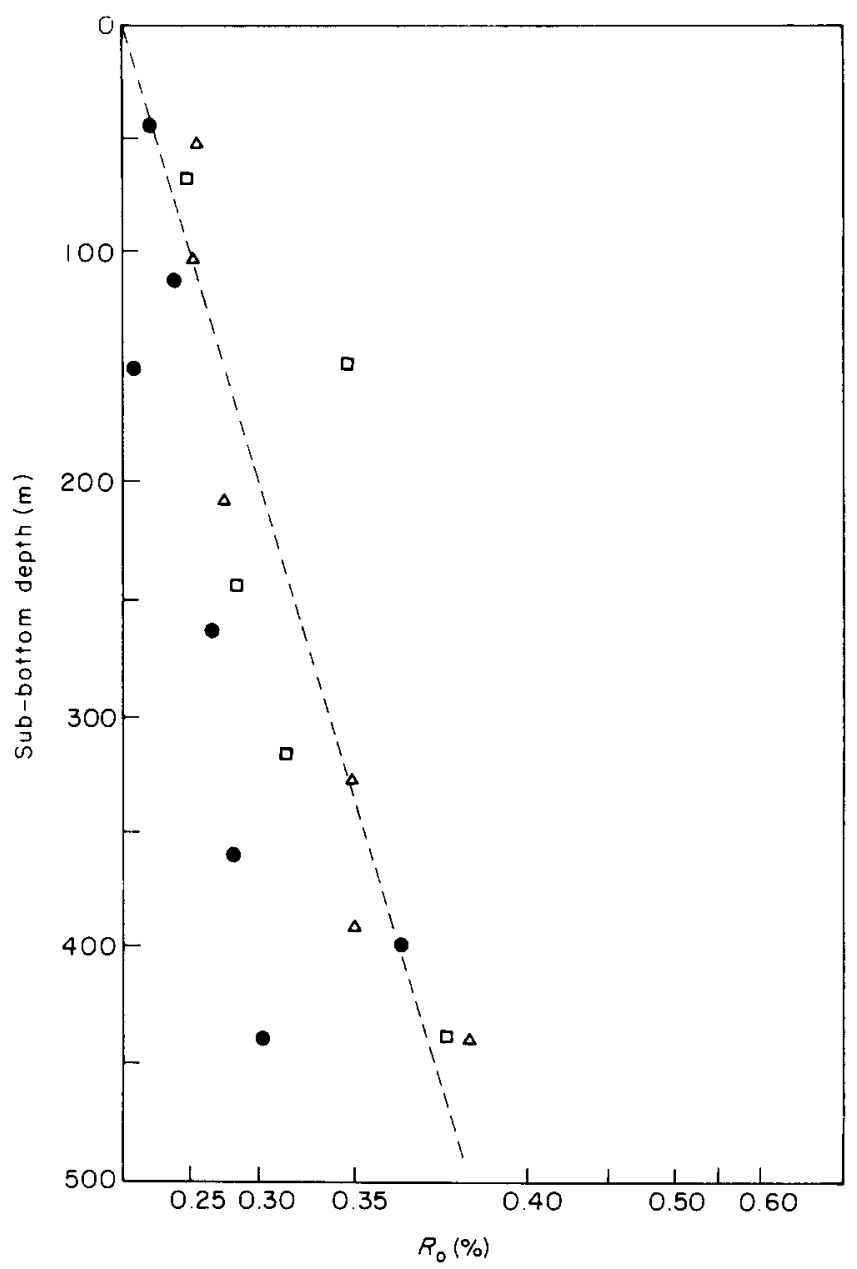

Figure 12 Downhole increase in thermaı maturity as measured by vitrinite reflectance $\left(\% R_{\mathrm{o}}\right)$ at Site 479 on the Guaymas continental slope. Dashed line is our best fit to data of (O) Kendrick (1982), ( $\triangle$ ) Peters and Simoneit (1982), and ( $\square$ ) Rullkötter et al. (1982) 
Hydrothermal alteration of organic matter: B. R. T. Simoneit et al.

hydrocarbons show an exponential increase downhole. further signifying that generation may be taking place. This trend is somewhat obscured by the tendency of the concentration of light hydrocarbons to follow the abundance of sediment organic matter (Whelan and Hunt, 1982). Plots of light hydrocarbon concentrations normalized to organic carbon versus vitrinite reflectance suggest that the downhole increase in these components is caused by maturation rather than migration (Figure 13). In addition, nickel porphyrins of probably a thermal diagenetic origin begin to appear near the bottom of Site 479 (Galimov et al., 1982).

Methane does not show the dependence on thermal stress that is evident in the gasoline-range components. Its carbon isotope composition remains about the same $(-60 \%)$ over much of the sediment sequence at Site 479 , suggesting its origin mostly from bacterial degradation of organic matter (Schoell, 1982; Galimov and Simoneit, 1982a, b; Simoneit and Galimov, 1984). Although the generation of gasoline-range components should be accompanied by the generation of at least some thermogenic methane, it appears that the volume of biogenic methane is so large that the thermogenic contribution is overwhelmed.

The evidence clearly suggests that some thermogenic hydrocarbons are being generated towards the bottom of the section at Site 479, despite the low levels of maturation measured there (Figure 12). Absolute amounts of hydrocarbons are rather low compared with those typical of the oil window. For instance, the sum of the $\mathrm{C}_{2}-\mathrm{C}_{8}$ alkanes reaches $1465 \mathrm{ng} / \mathrm{g}$ at $360 \mathrm{~m}$ at Site 479 (Whelan and Hunt, 1982). Similar values occur, for instance, in the Gulf of Mexico at depths of 2500-3500 $\mathrm{m}$, which is about $700-1000 \mathrm{~m}$ above the top of the oil window there (cf. Hunt et al., 1980). Other scientists (e.g. Leythaeuser et al., 1979) use the ratios of hydrocarbons to organic content, rather than the absolute concentration of hydrocarbons, to evaluate hydrocarbon generation (as we do in Figure 13). Using this approach, we calculate that the deepest three samples analysed by Whelan and Hunt (1982) from Site 479 have relative $n$-alkane concentrations of 29000-39000 ng hydrocarbons (sum of $\mathrm{C}_{2}-\mathrm{C}_{8}$ alkanes/g TOC). Leythaeuser et al. (1979) record similar relative abundances (for the $\mathrm{C}_{2}-\mathrm{C}_{7}$ alkanes) with analogous maturities for other areas above the oil window in sediments containing marine organic matter. In these places, however, the depths at which these relative abundances were measured are an order of magnitude greater, and the sediments are considerably older.

Clearly the Leg 64 data provide confirmation that light hydrocarbons, albeit in quantities an order of magnitude less than those typical of the oil window, are generated early. Presumably their generation in young, shallow sediment at Site 479 is caused by the locally high heat flow, which is $2.36 \mathrm{HFU}$ at this location (Curray et al., 1982: The thermal gradient here is $95.9^{\circ} \mathrm{C} \mathrm{km}^{-1}$, and the bottom hole temperature was
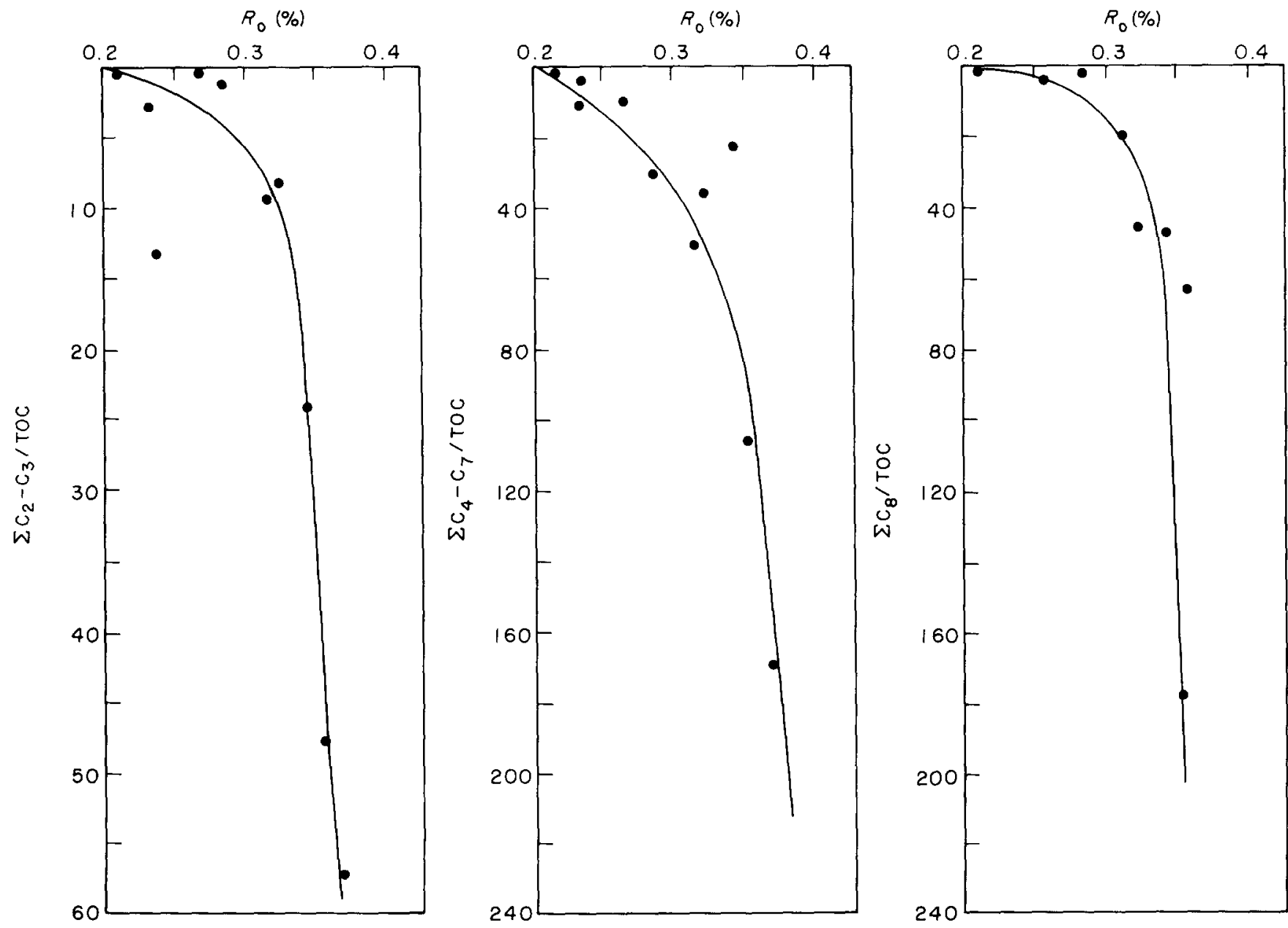

Figure 13 Interdependence of maturation (vitrinite reflectance, $\% R_{\mathrm{o}}$ ) and light hydrocarbon concentration at Site 479 on the Guaymas continental slope. $R_{\mathrm{o}}$ data interpolated from best fit line of Figure 12 ; ratios calculated from data in Whelan and Hunt (1982). Nature of section argues against diffusion and in favour of generation to explain trends 
$\left.49.5^{\circ} \mathrm{C}\right)$

Signs of thermal stress comparable to those observed in the organic geochemical data were not detected at this site in the mineralogical or inorganic geochemical data (Gieskes et al., 1982a; b), which points out that organic substances are indeed sensitive to thermal effects.

\section{Paleoenvironmental changes}

The distribution of organic matter downhole is not governed simply by changing degrees of preservation or supply between the laminated and homogeneous zones. LeClaire and Kelts (1982) show that these different zones have similar TOC values. This observation supports the contention of Schrader (1982) that bioturbation is incomplete in the homogeneous zones. Nevertheless, there appear to be subtle differences in organic geochemistry between these zones. For instance, the homogeneous ones have a higher proportion of terrigenous organic matter than do the laminated ones (Simoneit, 1983b). This could reflect the consumption of the more easily degradable marine fraction when oxygen levels were high. It could also equally represent a more marine organic input when the climate was dry and upwelling was strong, compared with a more terrigenous input when the climate was wet and upwelling was reduced (cf. LeClaire and Kelts, 1982; Simoneit, 1983b).

The long record of laminations, extending back into the late Pliocene in Unit 3 sediments, suggests long-term climatic stability. Seasonal productivity during deposition of Unit 3 is reflected in the presence of very thin laminae consisting of fish scales and organic matter, but the amount of organic matter preserved is small compared with that in Unit 2. Inasmuch as organic matter, diatoms and nannofossils are not abundant in Unit 3, it appears that productivity was low at this time. However, the presence of laminations suggests that the bottom water may, nevertheless, have been anoxic. There does not necessarily have to be a link here between the productivity of surface water and the oxygenation of the oxygen minimum zone because the subsurface, oxygen-poor water of the Gulf is drawn in from the Pacific by the prevailing 'estuarine' circulation pattern (cf. Summerhayes, 1983).

\section{Conclusions}

High heat flow, in places accompanied by hydrothermal circulation, has caused extensive alteration and leaching of organic (as well as mineral) material in the Quaternary sediments on and near the young, active spreading centres in the Gulf of California. Two types of hydrothermal activity have been involved. The first, of short duration, is by sill intrusion and is associated with maturation confined to the immediate vicinity of the respective sill (e.g. Sites 477,478 , and 481). The second is of longer duration, involving more deeply seated magma chambers and is associated with extensive maturation and migration (e.g. Site 477). Even at some distance from the spreading centres, as at Site 479 on the mainland passive margin of Mexico, the heat flow is still moderately high and young, shallow sediments are approaching maturity and generating small amounts of light hydrocarbons at sub-bottom depths of 300-500 m.
Migration of thermally generated hydrocarbons, apart from methane, is apparent close to sills and in the extensive hydrothermally altered section deep at Site 477, but not elsewhere. Thermogenic methane, in contrast, is common at low concentrations in the deep Guaymas Basin sediments, though not on the basin margins.

The bulk of the sedimentary organic matter both in the Guaymas Basin and on its margin is marine. A subordinate terrigenous component is locally predominant - especially in turbidite horizons deep in Site 481 . In the laminated diatomites on the Guaymas margin, the terrigenous organic fraction is most abundant in bioturbated zones. These homogeneous zones seem to have formed when the climate was wetter, runoff was higher, productivity was lower, and anoxia less well developed than during times when laminated sediments accumulated.

The sediments of ancient basin analogues with similarly high past heat flows may have experienced comparable patchy maturation before cooling and further burial. Their petroleum potential is likely to have been exhausted by continued maturation wherever burial has been sufficient. While their maturation history may resemble that of Gulf of California sediments, their petroleum potential may not. For instance, another modern spreading centre, the Red Sea, is oxygenated and relatively less productive than the Gulf of California, so it is not accumulating significant amounts of organic-rich sediment: The key to organic enrichment is productivity and oxygen, which govern supply and preservation of organic matter (e.g. Didyk et al., 1978; Demaison and Moore, 1980; Summerhayes, 1983).

\section{Acknowledgements}

We appreciate the helpful comments of A. S. Mackenzie and an anonymous reviewer in improving this paper. We are grateful to J. Gieskes for allowing us the use of his illustration. C.P.S. thanks British Petroleum for permission to publish this paper. B.R.T.S. thanks the US National Science Foundation for access to DSDP samples, for his participation in DSDP Leg 64, and for providing partial support for some of the research described in this report (Grants OCE 81-18897 and OCE 83-12036).

\section{References}

Baker, E.W. and Louda, J.W. (1982). Geochemistry of tetrapyrrole, tetraterpenoid, and perylene pigments in sediments from the Gulf of California: Deep Sea Drilling Project Leg 64, Sites 474, 477, 479, and 481, and Scripps Institution of Oceanography Guaymas Basin Survey Cruise Leg 3, Sites 10G and 18G, in: Init. Rpts. DSDP, Vol. 64, (Eds. Curray, J.R., Moore, D.G., et al.) US Govt. Print. Office, Washington, D.C., pp. 789-814

Calvert, S.E. (1964). Factors affecting distribution of laminated diatomaceous sediments in Gulf of California, in: Marine Geology of the Gulf of California, (Eds. van Andel, T.J., and Shor, G.G.) AAPG Memoir 3, Tulsa, pp. 311-330

Curray, J.R., Moore, D.G., Aguayo, J.E., Aubry, M.P., Einsele, G., Fornari, D., Gieskes, J., Guerrero, J., Kastner, M., Kelts, K., Lyle, M., Matoba, Y., Molina-Cruz, A., Niemitz, J., Rueda-Gaxiola, J., Saunders, A., Schrader, H., Simoneit, B.R.T., and Vacquier, V. (1979). Leg 64 seeks evidence on development of basins, Geotimes 24(7), 18-20 
Hydrothermal alteration of organic matter: B. R. T. Simoneit et al.

Curray, J.R., Moore, D.G., Aguayo, J.E. et al., (1982). Initial Reports of the Deep Sea Drilling Project, Vol. 64, Parts 1 and 2, US Govt. Print. Office, Washington, D.C., $1313 \mathrm{pp}$

Demaison, G.J. and Moore, G.T., 1980. Anoxic environments and oil source bed genesis. Am. Assoc. Pet. Geol. Bull. 64, 1179-1209

Deroo, G., Herbin, J.P., Roucaché, J., Boudou, J.P., Robert, P. Jardine, S. and Marestang, P., (1982). Geochemical and optical study of organic matter in some Pleistocene and Pliocene sediment from the Gulf of California: Leg 64, Holes 474 to $481 \mathrm{~A}$, in: Init. Rpts. DSDP, Vol. 64, (Eds. Curray, J.R. Moore, D.G., et al.) US Govt. Print. Office, Washington, D.C., pp. 855-864

Didyk, B.M., Simoneit, B.R.T., Brassell, S.C. and Eglinton, G. (1978). Organic geochemical indicators of palaeoenvironmental conditions of sedimentation, Nature 272, 216-222.

Dow, W.G., 1977. Kerogen studies and geological interpretations, J. Geochem. Explor. 7, 77-79

Einsele, G., Gieskes, J.M., Curray, J., et al. (1980). Intrusion of basaltic sills into highly porous sediments, and resulting hydrothermal activity, Nature 283, 441-445

Galimov, E.M. and Simoneit, B.R.T. (1982a). Geochemistry of interstitial gases in sedimentary deposits of the Gulf of California, Deep Sea Drilling Project Leg 64, in: Initial Reports of the Deep Sea Drilling Project, Vol. 64, (Eds. Curray, J.R. Moore, D.G., et al.) US Govt. Print. Office, Washington, D.C., pp. 781-788

Galimov, E.M. and Simoneit, B.R.T., (1982b). Variations in the carbon isotope compositions of $\mathrm{CH}_{4}$ and $\mathrm{CO}_{2}$ in the sedimentary sections of Guaymas Basin, Gulf of California, Geokhimya 7, 1027-1034

Galimov, E.M., Kodina, L.A., Bogacheva, M.P. and Shirinsky, V.G. (1982). Organic geochemical studies of samples from Deep Sea Drilling Project Leg 64, Gulf of California, Sites 474, 477, 478, 479, and 481, in: Init. Rpts. DSDP, Vol. 64, (Eds. Curray, J.R., Moore, D.G., et al.) US Govt. Print. Office, Washington, D.C., pp. 819-836

Gieskes, J.M., Kaster, M., Einsele, G., Kelts, K. and Niemitz, J., 1982a. Hydrothermal activity in the Guaymas Basin, Gulf of California: A synthesis, in: Init. Repts. DSDP, Vol. 64, (Eds. Curray, J.R., Moore, D.G., et al.) US Govt. Print. Office, Washington, D.C., pp. 1159-1167

Gieskes, J., Elderfield, H., Lawrence, J.R., Johnson, J., Meyers, B. and Campbell, A. (1982b). Geochemistry of interstitial waters and sediments, Leg 64, Gulf of California, in: Init. Rpts. DSDP, Vol. 64, (Eds. Curray, J.R., Moore, D.G., et al.) US Govt. Print. Office, Washington, D.C., pp. 675-694

Gilbert, D. and Summerhayes, C.P. (1982). Organic facies and hydrocarbon potential in the Gulf of California, in: Init. Rpts. DSDP, Vol. 64, (Eds. Curray, J.R., Moore, D.G., et al.) US Govt. Print. Office, Washington, D.C., pp. $865-870$

Hites, R.A., LaFlamme, R.E. and Farrington, J.W. (1977). Polycyclic aromatic hydrocarbons in recent sediments: the historical record, Science 198, 829-831

Hites, R.A., LaFlamme, R.E., Windsor, J.G., Jr., Farrington, J.W. and Deuser, W.G. (1980). Polycyclic aromatic hydrocarbons in an anoxic sediment core from the Pettaquamscutt River (Rhode Island, USA), Geochim. Cosmochim. Acta 44, 873-878

Hoering, T.C. (1977). Olefinic hydrocarbons from Bradford, Pennsylvania, crude oil, Chem. Geol. 20, 1-8

Hunt, J.M., Huc, A.Y. and Whelan, J.K., 1980. Generation of light hydrocarbons in sedimentary rocks, Nature 288, 688-690

Jenden, P.D., Simoneit, B.R.T. and Philp, R.P. (1982). Hydrothermal effects on protokerogen of unconsolidated sediments from Guaymas Basin, Gulf of California: Elemental compositions, stable carbon isotope ratios, and electron-spin resonance spectra, in: Init. Rpts. DSDP, Vol. 64, (Eds. Curray, J.R., Moore, D.G., et al.) US Govt. Print. Office, Washington, D.C., pp. 905-912

Kendrick, J.W. (1982). Petroleum-generating potential of sediment in the Gulf of California, in: Init. Rpts. DSDP, Vol 64, (Eds. Curray, J.R., Moore, D.G., et al.) US Govt. Print. Office, Washington, D.C., pp. 871-875

LaFlamme, R.E. and Hites, R.A. (1978). The global distribution of polycyclic aromatic hydrocarbons in recent sediments, Geachim. Cosmochim. Acta 43, 289-304

LeClaire, J.P. and Kelts, K. (1982). Calcium carbonate and organic carbon stratigraphy of late Quaternary laminated and homogeneous diatom oozes from the Guaymas slope,
HPC Site 480, Gulf of California, in: /nit. Repts. DSDP, Vol. 64, (Eds. Curray, J.R., Moore, D.G., et al.) US Govt. Print. Office, Washington, D.C., pp. 1263-1275

Leythaeuser, D., Schaefer, R.G., Cornford, C. and Weiner, B., 1979. Generation and migration of light hydrocarbons $\left(\mathrm{C}_{2}-\mathrm{C}_{7}\right)$ in sedimentary basins. Org. Geochem. 1, 191-204

Louda, J.W. and Baker, E.W. (1981). Geochemistry of tetrapyrrole, carotenoid and perylene pigments from the San Miguel Gap (Site 467) and Baja California Borderland (Site 471), Deep Sea Drilling Project Leg 63, in: Init. Rpts. of DSDP, Vol. 63, (Eds. Yeats, R.S., Haq, B.U., et. al.) US Govt. Print. Office, Washington, D.C., pp. 785-818

Meyers, P.A., Brassell, S.C. and Huc, A.Y. (1983). Organic matter patterns in South Atlantic sediments deposited since the late Miocene beneath the Benguela upwelling system, in: Advances in Organic Geochemistry 1981, (Eds. M. Bjorøy, et al.), John Wiley, Chichester, pp. 465-470

Oremland, R.S., Culbertson, C. and Simoneit, B.R.T. (1982). Methanogenic activity in sediment from Leg 64 , Gulf of California, in: Init. Rpts. DSDP, Vol. 64, (Eds. Curray, J.R., Moore, D.G., et. al.) US Govt. Print. Office, Washington, D.C., pp. 759-762

Peters, K.E., Simoneit, B.R.T., Brenner, S. and Kaplan, I.R., (1978). Vitrinite reflectance - temperature determinations for intruded Cretaceous black shale in the Eastern Atlantic, in: Symp. in Geochem: Low Temperature Metaphorphism of Kerogen and Clay Minerals, SEPM, Los Angeles, (Ed. Oltz, D.F.) pp. $53-58$

Peters, K.E. and Simoneit, B.R.T. (1982). Rock-Eval pyrolysis of Quaternary sediments from Leg 64, Sites 479 and 480 , Gulf of California, in: Init. Rpts. DSDP, Vol. 64 (Eds. Curray, J.R., Moore, D.G., et al.) US Govt. Print. Office, Washington, D.C., pp. 789-814

Rueda-Gaxiola, J., Morales, J. and Duenas, M.A. (1982). Optical analysis of the organic and inorganic constituents of the palynological residue in sediments from the mouth of the Gulf of California and Guaymas Basin, Deep Sea Drilling Project Leg 64: Sedimentological and diagenetic implications, in: Init. Rpts. DSDP, Vol. 64, (Eds. Curray, J.R., Moore, D.G., et al.) US Govt. Print. Office, Washington, D.C., pp. 729-731

Rullkötter, J., von der Dick, H. and Welte, D.H. (1981). Organic petrography and extractable hydrocarbons of sediments from the eastern North Pacific Ocean, Deep Sea Drilling Project, Leg 63, in: Init. Rpts. of DSDP, Vol. 63, (Eds. Yeats, R.S, Haq, B.U., et. al.) US Govt. Print. Office, Washington, D.C., pp. $819-836$

Rullkötter, J., von der Dick, H. and Welte, D.H. (1982). Organic petrography and extractable hydrocarbons of sediments from the Gulf of California, Deep Sea Drilling Project Leg 64, in: Init. Rpts. DSDP, Vol. 64, (Eds. Curray, J.R., Moore, D.G. et al.) US Govt. Print. Office, Washington, D.C., pp. 837-853

Ryther, J.H. (1956). Photosynthesis in the ocean as a function of light intensity, Limnol. Oceanogr. 1, 6-70

Schoell, M. (1982). Stable isotopic analyses of interstitial gases in Quaternary sediments from the Gulf of California, in: Init. Rpts. DSDP, Vol. 64, (Eds. Curray, J.R., Moore, D.G., et al.) US Govt. Print. Office, Washington, D.C., pp. 815-817

Schrader, H., Kelts, K., Curray, J., Moore, D., Aguayo, E., Aubry, M.P., Einsele, G., Fornari, D., Gieskes, J., Guerrero, J., Kastner, M., Lyle, M., Matoba, Y., Molina-Cruz, A., Niemitz, J., Rueda, J., Saunders, A., Simoneit, B. and Vaquier, V. (1980). Laminated diatomaceous sediments from the Guaymas Basin slope (Central Gulf of California): 250,000-year climate record, Science 207, 1207-1209

Schrader, H., 1982. Diatom biostratigraphy and laminated diatomaceous sediments from the Gulf of California Deep Sea Drilling Project Leg 64, in: Init. Rpts. DSDP, Vol. 64, (Eds. Curray, J.R., Moore, D.G., et al.) US Govt. Print. Office, Washington, D.C., pp. 973-981

Schrader, H. and Baumgartner, T., 1983. Decadal variation of upwelling in the Central Gulf of California, in: Coastal Upwelling, Its Sediment record; Part B, (Eds. Thiede, J. and Suess, E.) Plenum Press, New York, pp. 247-276

Simoneit, B.R.T., (1982a). Shipboard organic geochemistry and safety monitoring, Leg 64, Gulf of California, in: Init. Rpts. DSDP, Vol. 64, (Eds. Curray, J.R., Moore, D.G., et al.) US Govt. Print. Office, Washington, D.C., pp. 723-728

Simoneit, B.R.T. (1982b). Preliminary organic geochemistry of laminated versus non-laminated sediments from Holes 479 and 480, Deep Sea Drilling Project Leg 64, in: Init. Rpts. of 
DSDP, Vol. 64, (Eds. Curray, J.R., Moore, D.G., et al.) US Govt. Print. Office, Washington, D.C., pp. 921-924

Simoneit, B.R.T. (1983a). Organic matter maturation and petroleum genesis: Geothermal versus hydrothermal, in: Proc. Symp. The Role of Heat in the Development of Energy and Mineral Resources in the Northern Basin and Range Province, Geotherm. Res. Council, Davis, California, pp. 215-241

Simoneit, B.R.T. (1983b). Organic geochemistry of laminated sediments from the Gulf of California, in: Coastal Upwelling, Its Sediment Record, Part l, Responses of the Sedimentary Regime to Present Coastal Upwelling, (Eds. Suess, E. and Thiede, J.) NATO Adv. Res. Inst., Plenum Publishing Corp., New York, pp. 527-544

Simoneit, B.R.T. (1983c). Effects of hydrothermal activity on sedimentary organic matter: Guaymas Basin, Gulf of California - Petroleum genesis and protokerogen degradation, in: NATO-ARI: Hydrothermal Processes at Seafloor Spreading Centers, (Eds. Bostrum, K. et al.), Plenum Press, New York, pp. 451-471

Simoneit, B.R.T. (1984). Hydrothermal effects on organic matter high versus low temperature components, Organic Geochem. 6, 857-864

Simoneit, B.R.T. (1985). Hydrothermal petroleum: Composition and utility as a biogenic carbon source. Bull. Biol. Soc. Washington, 6, 49-56

Simoneit, B.R.T. and Mazurek, M.A. (1981). Organic geochemistry of sediments from the Southern California Borderland, Deep Sea Drilling Project Leg 63, in: Init. Rpts. of DSDP, Vol. 63, (Eds. Yeats, R.S., Haq, B.U., et al.) US Govt. Print. Office, Washington, D.C., pp. 837-853

Simoneit, B.R.T. and Philp, R.P. (1982). Organic geochemistry of lipids and kerogen and the effects of basalt intrusions on unconsolidated oceanic sediments: Sites 477,478 , and 481 , Guaymas Basin, Gulf of California, in: Init. Rpts. of DSDP, Vol. 64, (Eds, Curray, J.R., Moore, D.G. et al.) US Govt. Print. Office, Washington, D.C., pp. 883-904

Simoneit, B.R.T. and Lonsdale, P.F. (1982). Hydrothermal petroleum in mineralized mounds at the seabed of Guaymas Basin, Nature 295, 198-202

Simoneit, B.R.T. and Bode, G.W. (1982). Appendix II. Carbon/carbonate and nitrogen analyses, Leg 64, Gulf of California, in: Init. Rpts. DSDP, Vol. 64, (Eds. Curray, J.R., Moore, D.G., et al.) US Govt. Print. Office, Washington, D.C., pp. 1303-1305

Simoneit, B.R.T. and Galimov, E.M. (1984). Geochemistry of interstitial gases in Quaternary sediments of the Gulf of California, Chem. Geol. 43, 151-166
Simoneit, B.R.T. and Kawka, O.E. (1986). Hydrothermal petroleum from diatomites in the Gulf of California, in: Marine Petroleum Source Rocks, (Eds. Brooks, J. and Fleet, A.), Geol. Soc. Lond., Special Publication, No. 24

Simoneit, B.R.T., Brenner, S., Peters, K.E. and Kaplan, I.R. (1978). Thermal alteration of Cretaceous black shale by basaltic intrusions in the Eastern Atlantic, Nature, 273, 501-504

Simoneit, B.R.T., Mazurek, M.A., Brenner, S. and Kaplan, I.R. (1979). Organic geochemistry of Recent sediments from Guaymas Basin, Gulf of California, Deep Sea Research, 26A, 879-891

Simoneit, B.R.T., Brenner, S., Peters, K.E. and Kaplan, I.R. (1981). Thermal alteration of Cretaceous black shale by diabase intrusions in the Eastern Atlantic - II. Effects on bitumen and kerogen, Geochim. Cosmochim. Acta 45, 1581-1602

Simoneit, B.R.T., Summerhayes, C.P. and Meyers, P.A. (1982). Sources, preservation, and maturation of organic matter in Pliocene and Quaternary sediments of the Gulf of California: A synthesis of organic geochemical studies from Deep Sea Drilling Project Leg 64, in: Init. Rpts. DSDP, Vol. 64 (Eds. Curray, J.R., Moore, D.G., et al.) US Govt. Print. Office, Washington, D.C., pp. 939-951

Simoneit, B.R.T., Philp, R.P., Jenden, P.D. and Galimov, E.M. (1984). Organic geochemistry of Deep Sea Drilling Project sediments from the Gulf of California - Hydrothermal effects on unconsolidated diatom ooze, Org. Geochem. 7, 173-205

Summerhayes, C.P. (1981). Oceanographic controls on organic matter in the Miocene Monterey Formation off-shore California, in: The Monterey Formation and Related Siliceous Rocks of California, (Eds. Garrison, R.E. and Douglas, R.G.) Spec. Publ. Pac. Sect., SEPM, Los Angeles, pp. 213-220

Summerhayes, C.P. (1983). Sedimentation of organic matter in upwelling regions, in: Coastal Upwelling - Its Sediment Record, Part B, (Eds. Thiede, J. and Suess, E.) Plenum Press, New York, pp. 29-72

Thomson, I.D., Brassell, S.C., Eglington, G. and Maxwell, J.R. (1982). Preliminary lipid analysis of Section 481-2-2, in: Init. Rpts. DSDP, Vol. 64, (Eds. Curray, J.R., Moore, D.G., et al.) US Govt. Print. Office, Washington, D.C., pp. 913-919

Wakeham, S.G., Schaffner, C., Giger, W., Boon, J.J. and DeLeeuW, J.W., (1979). Perylene in sediments from the Namibian Shelf, Geochim. Cosmochim. Acta 43, 1141-1144

Whelan, J.K. and Hunt, J.M. (1982). $C_{1}-C_{8}$ hydrocarbons in Leg 64 sediments, Gulf of California, in: Init. Rpts. DSDP, Vol. 64 (Eds. Curray, J.R., Moore, D.G., et al.) US Govt. Print. Office, Washington, D.C., pp. 763-779 